\title{
Evidence for a Fragile X Mental Retardation Protein- Mediated Translational Switch in Metabotropic Glutamate Receptor-Triggered Arc Translation and Long-Term Depression
}

\author{
Farr Niere, Julia R. Wilkerson, and Kimberly M. Huber \\ Department of Neuroscience, University of Texas Southwestern Medical Center, Dallas, Texas 75390
}

Group 1 metabotropic glutamate receptor (mGluR)-stimulated protein synthesis and long-term synaptic depression (mGluR-LTD) are altered in the mouse model of fragile X syndrome, Fmrl knock-out (KO) mice. Fmrl encodes fragile X mental retardation protein (FMRP), a dendritic RNA binding protein that functions, in part, as a translational suppressor. It is unknown whether and how FMRP acutely regulates LTD and/or the rapid synthesis of new proteins required for LTD, such as the activity-regulated cytoskeletal-associated protein (Arc). The protein phosphatase PP2A dephosphorylates FMRP, which contributes to translational activation of some target mRNAs. Here, we report that PP2A and dephosphorylation of FMRP at S500 are required for an mGluR-induced, rapid (5 min) increase in dendritic Arc protein and LTD in rat and mouse hippocampal neurons. In Fmr1 KO neurons, basal, dendritic Arc protein levels and mGluR-LTD are enhanced, but mGluR-triggered Arc synthesis is absent. Lentiviral-mediated expression of wild-type FMRP in Fmr1 KO neurons suppresses basal dendritic Arc levels and mGluR-LTD, and restores rapid mGluR-triggered Arc synthesis. A phosphomimic of FMRP (S500D) suppresses steady-state dendritic Arc levels but does not rescue mGluR-induced Arc synthesis. A dephosphomimic of FMRP (S500A) neither suppresses dendritic Arc nor supports mGluR-induced Arc synthesis. Accordingly, S500D-FMRP expression in Fmr1 K0 neurons suppresses mGluR-LTD, whereas S500A-FMRP has no effect. These data support a model in which phosphorylated FMRP functions to suppress steady-state translation of Arc and LTD. Upon mGluR activation of PP2A, FMRP is rapidly dephosphorylated, which contributes to rapid new synthesis of Arc and mGluR-LTD.

\section{Introduction}

Fragile $\mathrm{X}$ syndrome is caused by loss-of-function mutations in the fragile $\mathrm{X}$ mental retardation gene $(F m r 1)$ and is the most common inherited form of intellectual disability and autism (Penagarikano et al., 2007; Abrahams and Geschwind, 2008). Fmr1 encodes fragile X mental retardation protein (FMRP), an RNA-binding protein that may regulate dendritic mRNA translation (Bassell and Warren, 2008; Zukin et al., 2009). Synaptic plasticity that relies on dendritic protein synthesis is abnormal in Fmr1 knock-out (KO) mice. Specifically, activation of group 1 (Gp1) metabotropic glutamate receptors (mGluRs) in hippocampal CA1 neurons results in a long-term depression of ex-

Received Sept. 12, 2011; revised Jan. 19, 2012; accepted March 13, 2012.

Author contributions: F.N. and K.M.H. designed research; F.N. and J.R.W. performed research; F.N. and J.R.W. analyzed data; F.N. and K.M.H. wrote the paper.

This work was supported by National Institutes of Health Grants NS045711, HD052731 (K.M.H.), HD052731S1 (F.N.), and F32HD06212001 (J.R.W.), and by Autism Speaks (K.M.H.). We thank Drs. Gary Bassell and Christina Gross for help with the Arc FISH experiments, Dr. Paul Worley for the gift of an Arc antibody, and Lorea Ormazabal, Nicole Cabalo, and Seth Hays for technical assistance with the Fmr $1 \mathrm{KO}$ and GFP/Fmr 1 mosaic mice.

The authors declare no competing financial interests.

Correspondence should be addressed to Dr. Kimberly M. Huber, Department of Neuroscience, University of Texas Southwestern Medical Center, 5323 Harry Hines Boulevard, NA4.118, Dallas, TX 75390-9011. E-mail: kimberly.huber@utsouthwestern.edu.

DOI:10.1523/JNEUROSCI.4650-11.2012

Copyright $(2012$ the authors $\quad 0270-6474 / 12 / 325924-13 \$ 15.00 / 0$ citatory synaptic transmission (mGluR-LTD) that requires rapid, dendritic protein synthesis and is mediated by a reduction in postsynaptic AMPA receptor number (Waung and Huber, 2009). In Fmr1 KO mice, mGluR-LTD is enhanced and independent of new protein synthesis (Huber et al., 2002; Hou et al., 2006; Nosyreva and Huber, 2006). One function of FMRP is to suppress translation of its target mRNAs (Napoli et al., 2008; Darnell et al., 2011). Therefore, in Fmr1 KO mice, loss of FMRPmediated translational suppression may lead to elevated steadystate levels of "LTD proteins" and LTD that occurs in the absence of new protein synthesis (Nosyreva and Huber, 2006).

A candidate "LTD protein" is the activity-regulated cytoskeletalassociated protein (Arc) (Park et al., 2008; Waung et al., 2008). $A r c$ is an immediate-early gene that is induced in neurons in response to salient experience (Link et al., 1995; Lyford et al., 1995). Arc translation likely contributes to encoding of these experiences because it is necessary for learning and experiencedependent synaptic and behavioral plasticity (Bramham et al., 2010). Upon induction, $A r c$ mRNA is rapidly transported to dendrites, where it is dendritically translated in response to mGluR stimulation (Steward et al., 1998b; Park et al., 2008; Waung et al., 2008). Arc is required for mGluR-LTD in both wild-type (WT) and Fmrl KO mice (Park et al., 2008; Waung et al., 2008), where it functions to stimulate endocytosis of AMPARs (Chowdhury et 
al., 2006). $\operatorname{Arc}$ mRNA interacts with FMRP (Zalfa et al., 2003; Iacoangeli et al., 2008), but it is unknown whether or how FMRP regulates dendritic Arc translation under basal conditions or during plasticity.

Although FMRP functions as a translational suppressor, recent work demonstrates that mGluRs trigger PP2A-mediated dephosphorylation of FMRP, which functions to de-repress or activate translation of FMRP target mRNAs (Bassell and Warren, 2008). Phosphorylation of FMRP at a conserved serine (Ser500 in humans) is more associated with stalled polyribosomes and also stabilizes a microRNA-AGO2 complex with Psd95 mRNA, suppressing its translation (Ceman et al., 2003; Muddashetty et al., 2011). mGluR stimulation of neurons rapidly ( $<1 \mathrm{~min})$ activates PP2A, which dephosphorylates FMRP at Ser500, and stimulates translation of the FMRP target mRNAs, Sapap3 and Psd95 (Narayanan et al., 2007, 2008; Muddashetty et al., 2011). The role of rapid translational regulation by FMRP or its dephosphorylation in neuronal or synaptic function is unknown. Here, we provide evidence that PP2A and FMRP dephosphorylation function as a translational switch in mGluR-stimulated dendritic Arc translation and LTD.

\section{Materials and Methods}

Dissociated hippocampal neurons

Neuronal cultures were prepared from the CA1/CA3 hippocampal regions of $\mathrm{P} 0-\mathrm{P} 2$ male hooded Long-Evans rats, and male and female WT or Fmr1 KO (C56BL/6CR strain) or Arc KO mice as described previously (Volk et al., 2007; Waung et al., 2008). Arc KO mice were obtained from Dr. Kuan Hong Wang (National Institute of Mental Health-NIH, Bethesda, MD) (Wang et al., 2006) and backcrossed to C57BL/6CR mice. Neurons were plated in Neurobasal A medium supplemented with B27, $0.5 \mu \mathrm{M}$ glutamine, and $1 \%$ fetal bovine serum at a density of $\sim 400$ neurons $/ \mathrm{mm}^{2}$ onto glass coverslips coated overnight with $50 \mu \mathrm{g} / \mathrm{ml}$ poly-Dlysine and $25 \mu \mathrm{g} / \mathrm{ml} \mathrm{laminin.} \mathrm{Cultures} \mathrm{were} \mathrm{fed} \mathrm{at} 1 \mathrm{~d}$ in vitro (DIV), and medium was replaced once a week thereafter with glial-conditioned media from wild-type mouse glial cultures as described previously (Viviani, 2006). Experiments were performed at 18-21 DIV.

\section{Immunocytochemistry}

All experiments were performed on at least three independent cultures with two to three different coverslips per condition. For Arc, tubulin, and GFP immunofluorescence, neurons were fixed and permeabilized with ice-cold methanol $(10 \mathrm{~min})$, or fixed in $4 \%$ paraformaldehyde $\left(37^{\circ} \mathrm{C}, 15\right.$ $\mathrm{min}$ ) and permeabilized in $0.2 \%$ Triton X (10 min). Fixed cells were incubated in primary anti-Arc [1:600; Synaptic Systems; 1:100; gift from Dr. Paul Worley (The Johns Hopkins University, Baltimore, MD) (Lyford et al., 1995)], primary anti- $\beta 3$-tubulin (1:600; Abcam), primary anti-microtubule-associated protein 2 (MAP2) (1:1000; Millipore), and primary anti-GFP (1:600; Aves Labs). Primary antibodies were detected with subsequent application of the appropriate Alexa Fluor 555 (AF555)-, AF546-, AF488-, or AF633-conjugated secondary antibody (Invitrogen). To confirm the specificity of both anti-Arc antibodies used in this study, we performed immunocytochemistry in dissociated hippocampal neuron cultures prepared from WT and Arc KO littermates (Wang et al., 2006). Figure $1 E$ demonstrates the results with the Synaptic Systems antibody. Similar results were observed using the Arc antibody provided by Dr. Paul Worley (data not shown). Fluorescence images were acquired on a Nikon TE2000 microscope with a cooled CCD camera (CoolSnap HQ; Roper Scientific) and quantified with MetaMorph Meta Imaging Series software (Molecular Devices). For a given experiment, images of cells across all conditions were collected on the same day using the same duration and intensity of excitation light. For acquisition of dendritic images, an oil-immersion, $63 \times$ objective lens was used; and for somatic images, a $20 \times$ objective lens was used. Healthy neurons were first identified by their smooth soma and multiple processes under differential interference contrast (DIC) microscopy. Using MetaMorph, images used for somatic and dendritic analyses were set at a threshold value of at least thrice above background, which remained constant within an experiment. For dendritic images, background values for each image were obtained by measuring the average fluorescence intensity in a circular region of $\sim 70 \mu \mathrm{m}^{2}$ adjacent to a neuron. The product of the total area and intensity above threshold of dendritic fluorescence that was at least thrice the background was quantified and normalized to the control (untreated or basal) conditions for each experiment. Dendritic Arc immunofluorescence was analyzed in the most proximal $50 \mu \mathrm{m}$ section of secondary dendrites (three per cell). The fluorescence values of three dendrites were averaged and represented the value for a cell. A cell equals an $n$ of 1 . Ten to 15 cells were analyzed per coverslip per condition. For somatic Arc measurement, we quantified the product of the total area and intensity above threshold in a circular area of $\sim 60 \mu \mathrm{m}^{2}$, which was placed in the center of a cell body. The threshold value was at least thrice the background. To obtain background values for somatic imaging analysis, we measured the average fluorescence intensity in a circular area of $\sim 60 \mu \mathrm{m}^{2}$ within each region that was imaged. Five to 10 regions from each coverslip were taken. Ten to 30 cell somas from each coverslip were analyzed. Two to three different coverslips were used for each condition. To aid the visualization of images in the figures, background fluorescence was manually subtracted using the "adjust levels" tool in Adobe Photoshop. For a given experiment, levels were adjusted in exactly the same manner as to maintain the same ratio of intensities across experimental conditions.

\section{Lentivirus production}

FMRP GFP was cloned into the lentiviral vector FUGW (Lois et al., 2002) obtained from Dr. Thomas Sudhof (Stanford University, Stanford, CA). The FUGW vector was digested with EcoRI and BamHI, and the $9136 \mathrm{bp}$ product was gel purified. The human wt-FMRP ${ }^{\mathrm{GFP}}$-hpr construct described previously (Darnell et al., 2005; Pfeiffer and Huber, 2007) was digested with EcoRI, and the 5411 bp product was gel purified and digested with BamHI. The 2593 bp product from the BamHI digestion of wt-FMRP ${ }^{\text {GFP }}$-hpr was gel purified and ligated to the 9136 bp product of the FUGW digestion. The lentiviral constructs of S500DFMRP GFP and S500AFMRP GFP were made similarly as the FUGW-FMRP GFP ${ }^{\text {G }}$ using the FMRP-S500D-EGFP-hpr and FMRP-S500A-EGFP-hpr, respectively, as described previously (Pfeiffer and Huber, 2007). For the production of lentivirus, HEK293 cells were transfected with FMRP GFP or FMRP phosphomutants and three helper plasmids ( $p R S V, p M D L g$, and VSVG) using the FuGENE transfection reagent (Roche) according to the manufacturer's directions. After $48 \mathrm{~h}$, the medium was collected, filtered through a $0.45 \mu \mathrm{m}$ filter, aliquoted, and stored at $-80^{\circ} \mathrm{C}$. Hippocampal cultures were infected at $7-10 \mathrm{DIV}$ at a titer $(\sim 250-300 \mathrm{U} / \mu \mathrm{l})$ to infect $\sim 85 \%$ of neurons and analyzed at $18-21$ DIV.

\section{Fluorescence in situ hybridization}

Antisense and sense oligonucleotide probes to Arc mRNA were obtained from Dr. Gary Bassell (Emory University, Atlanta, GA) and labeled with digoxigenin (Dig) (Roche). Fluorescence in situ hybridization (FISH) was performed as previously described (Antar et al., 2004; Dictenberg et al., 2008). Summarily, probes were detected by immunofluorescence with a Cy3-conjugated mouse anti-Dig antibody and a Cy3-conjugated anti-mouse IgG antibody (Jackson ImmunoResearch). Sense oligonucleotides against $A r c$ were used as negative controls. Experiments were performed on at least three separate cultures.

\section{Electrophysiology}

Slices. Hippocampal slices $(400 \mu \mathrm{m})$ were prepared from postnatal day 21-55 hooded Long-Evans rats as described previously (Volk et al., 2007). Dissected hippocampi were sliced in ice-cold dissection buffer containing the following (in mM): $2.6 \mathrm{KCl}, 1.25 \mathrm{NaH}_{2} \mathrm{PO}_{4}, 26 \mathrm{NaHCO}_{3}$, $0.5 \mathrm{CaCl}_{2}, 5 \mathrm{MgCl}_{2}, 212$ sucrose, and 10 dextrose using a vibratome (Leica VT 1000S). The slices were transferred into a recovery chamber filled with ACSF containing the following (in $\mathrm{mm}$ ): $124 \mathrm{NaCl}, 5 \mathrm{KCl}$, $1.25 \mathrm{NaH}_{2} \mathrm{PO}_{4}, 26 \mathrm{NaHCO}_{3}, 2 \mathrm{CaCl}_{2}, 1 \mathrm{MgCl}_{2}$, and 10 dextrose for $1-5 \mathrm{~h}$. For recordings, slices were transferred to a submerged recording chamber, maintained at $30^{\circ} \mathrm{C}$, and perfused continuously with ACSF at a rate of $2-3 \mathrm{ml} / \mathrm{min}$. Extracellular field potentials (FPs) were recorded with glass electrodes $(1 \mathrm{M} \Omega$ ) filled with ACSF and placed in 
the stratum radiatum of area CA1. FPs were evoked by monophasic stimulation (200 $\mu$ s duration) of Schaffer collateral/commissural afferents with a concentric bipolar tungsten stimulating electrode. Stable baseline responses were collected every $30 \mathrm{~s}$ using a stimulation intensity $(10-30 \mu \mathrm{A})$ yielding $50-60 \%$ of the maximal response. The initial slope of the FPs was used to measure stability of synaptic responses and quantify the magnitude of LTD. Chemically induced mGluR-LTD was elicited by application of $100 \mu \mathrm{M}$ (RS)-3,5dihydroxyphenylglycine (DHPG) for $5 \mathrm{~min}$.

Dissociated neuron cultures. Whole-cell voltage-clamp recordings were performed on dissociated hippocampal neurons from WT, Fmr1 KO, and infected Fmr1 KO (GFP, wild-type FMRP ${ }^{\text {GFP }}$, S500A-FMRP GFP, S500D-FMRP $\left.{ }^{\mathrm{GPP}}\right)$. All experiments were performed on at least three separate cultures. Cells were visualized using infrared-DIC and GFP fluorescence to identify infected and noninfected neurons. Patch electrodes (3-7 $\mathrm{M} \Omega$ ) were filled with the following (in mM): 0.1 EGTA, 125 K-gluconate, $2.6 \mathrm{KCl}, 1.3 \mathrm{NaCl}, 10$ HEPES, 4 ATP-Mg, 0.3 GTP-Na, 14 phosphocreatine-Tris, $\mathrm{pH} 7.2$, adjusted to $285 \mathrm{mOsm}$ with sucrose or $\mathrm{H}_{2} \mathrm{O}$. Cells were perfused at room temperature at $0.5 \mathrm{ml} / \mathrm{min}$ in Tyrode's solution composed of the following (in $\mathrm{mm}$ ): $150 \mathrm{NaCl}, 4 \mathrm{KCl}, 2$ $\mathrm{MgCl}_{2} \cdot 6 \mathrm{H}_{2} \mathrm{O}, 10$ glucose, 10 HEPES, $2 \mathrm{CaCl}_{2} \cdot 2 \mathrm{H}_{2} \mathrm{O}, 0.1$ picrotoxin, 0.001 TTX, pH 7.4, adjusted to $310 \mathrm{mOsm}$. Cells were voltage clamped at -60 $\mathrm{mV}$. Series resistance and input resistance were measured in voltage clamp with $400 \mathrm{~ms},-10 \mathrm{mV}$ step from a $-60 \mathrm{mV}$ holding potential (Pfeiffer and Huber, 2007). Only cells with a holding current of $<200 \mathrm{pA}$ and a series resistance of $<40 \mathrm{M} \Omega$ were used for analysis. In addition, only cells that had a stable series resistance $(<25 \%$ change) after DHPG application were used. On average, DHPG did not affect series resistance within any experimental group (Table 1). mEPSCs were detected off-line using an automatic detection program (MiniAnalysis; Synaptosoft) with a detection threshold set at a value of $5 \times$ the RMS noise.

\section{Drug application}

For extracellular field potentials and Western blotting in slices, the slices were allowed to recover for $1 \mathrm{~h}$ and then incubated for at least $3 \mathrm{~h}$ in either ACSF $/ \mathrm{H}_{2} \mathrm{O}$ or ACSF/100 nm okadaic acid (OA). Brief DHPG application ( $100 \mu \mathrm{M}, 5 \mathrm{~min})$ was used to induce LTD in all of the experiments. Dissociated rat hippocampal neurons were preincubated in either 10 or $100 \mathrm{~nm} \mathrm{OA}$, or $100 \mathrm{~nm}$ fostriecin for $2 \mathrm{~h}$. Cultured mouse neurons were preincubated in $10 \mathrm{~nm}$ OA for $1 \mathrm{~h}$ because this was sufficient to enhance P-FMRP levels (see Fig. $3 C$ ), and we found $100 \mathrm{~nm}$ OA to be toxic to cultured mouse neurons. Similarly, incuba-

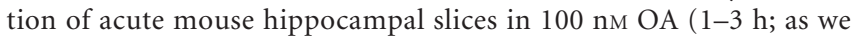
used in rat slices; see Fig. $1 \mathrm{~A}$ ) severely reduced their viability as observed by small or nonexistent FP recordings, which precluded us from investigating the role of PP2A in mGluR-LTD in slices from WT or Fmr1 KO mice. PP2A inhibitors were present before, during, and after DHPG stimulation. For protein synthesis inhibition, cultures were incubated in anisomycin $(20 \mu \mathrm{M}, 20 \mathrm{~min})$ before DHPG application and for the duration of the experiment.

\section{Western blot analysis}

For Western blots on dissociated hippocampal neurons (P18-P21), neurons were plated at a density of $4.5-5.0 \times 10^{4}$ cells, on 12 -mm-diameter coverslips, harvested in SDS sample buffer, and boiled at $90^{\circ} \mathrm{C}$ for $10 \mathrm{~min}$. A minimum of three coverslips were used for each condition. For Western blots in hippocampal slices, slices were prepared as described for electrophysiology from 21- to 28-d-old WT and Fmr1 KO mice, and 21to 35-d-old hooded Long-Evans (Nosyreva and Huber, 2006). Slices were homogenized in RIPA buffer, and protein concentrations were measured with BCA protein assay (Pierce). Proteins were separated by SDS-PAGE and immunoblotted with primary antibodies against Arc (1:20,000; Synaptic Systems), FMRP [2F5-1 antibody; 1:2000 (Gabel et al., 2004); provided by Dr. Jennifer Darnell (Rockefeller University, New York, NY)], phospho-FMRP (1:400; Abcam), Akt (Cell Signaling; 1:5000), phospho-Akt (Cell Signaling; 1:5000), $\beta 3$ tubulin (1:5000; Abcam), ERK1/2 (1:5000; Cell Signaling), and actin (1:100,000; Millipore). Blots were washed and incubated in appropriate HRP-conjugated secondary antibody (1:5000; MP Biomedicals).
Bands were detected using enhanced chemiluminescence, and densitometric images from scanned films were analyzed with ImageJ. For optical density quantification, Arc and P-FMRP were normalized to a loading control. Actin, total ERK, or tubulin was used as loading controls because the levels were unchanged with the experimental manipulations. For total ERK, bands at 42 and $44 \mathrm{kDa}$ were quantified. All experiments were performed on at least three separate cultures or three separate pairs (WT/Fmr1 KO) of animals.

\section{Statistical analysis}

Student's $t$ test or two-way ANOVA, and post hoc Bonferroni's or Newman-Keuls multiple-comparison tests were used for statistical analysis, where indicated: ${ }^{\star} p<0.05,{ }^{* *} p<0.01,{ }^{* *} p<0.001$.

\section{Results}

\section{PP2A is necessary for an early, immediate phase of} mGluR-triggered LTD and increases in dendritic Arc protein To determine whether FMRP dephosphorylation and PP2A play a role in mGluR-LTD, we preincubated acute hippocampal slices prepared from mature Long-Evans rats in the PP2A inhibitor OA. We chose to use $100 \mathrm{nM}$ OA because OA is 100 times more effective against PP2A compared with PP1 (Swingle et al., 2007) and $3 \mathrm{~h}$ incubation of rat brain slices in $100 \mathrm{~nm}$ OA selectively inhibits PP2A over PP1 or PP2B (Gong et al., 2000). Furthermore, OA treatment of hippocampal slices (100 nM; $1-3 \mathrm{~h})$ is sufficient to increase phosphorylation of FMRP (at S499) and that of another PP2A substrate (Akt) (Padmanabhan et al., 2009) as observed with Western blotting using phosphospecific antibodies (Fig. $1 B$ ). Population or field EPSPs (FPs) were measured in stratum radiatum of area CA1 in response to extracellular stimulation of CA3 Schaffer collateral axons as described previously (Huber et al., 2000). LTD was induced with the Gp1 mGluR agonist DHPG [100 $\mu \mathrm{M} ; 5$ min (Huber et al., 2000)]. Preincubation in OA reduced LTD magnitude measured at 30-40 min after DHPG $(86 \pm 3 \%$ of baseline; $n=13)$ compared with interleaved vehicle-treated slices [vehicle (water); $76 \pm 2 \%$ of baseline; $n=$ 13 slices; $p<0.05$; Fig. $1 A$ ]. However, at $1 \mathrm{~h}$ after DHPG, LTD magnitude of OA-treated slices returned to similar levels as vehicle-treated controls (OA, $80 \pm 2 \%$; vehicle, $76 \pm 3 \%)$. These results suggested that $\mathrm{PP} 2 \mathrm{~A}$ is required for an early, but not a late phase of mGluR-LTD.

Brief mGluR stimulation results in a rapid ( $5 \mathrm{~min}$ ) and persistent increase in Arc levels lasting at least $1 \mathrm{~h}$ after DHPG application. Previous work demonstrated that the rapid increases in Arc in response to the Gp1 mGluR agonist, DHPG, were due to local translational activation of Arc in dendrites from preexisting mRNA (Park et al., 2008; Waung et al., 2008), whereas the later increases in Arc protein are likely due to mGluR-induced transcription of Arc (Park et al., 2008; Taylor et al., 2010). We hypothesized that the role of PP2A in mGluR-LTD is to regulate rapid, FMRP-mediated translational control of LTD proteins, such as Arc, in dendrites. To test this idea, we examined the effects of PP2A inhibitors on DHPG-induced increases in dendritic Arc protein in dissociated hippocampal neuron cultures using immunocytochemistry. Pretreatment of cultures with OA (10 $\mathrm{nM} ; 1 \mathrm{~h}$ ) blocked mGluR-induced increases in dendritic Arc levels observed at $5 \mathrm{~min}$ after DHPG treatment, but did not affect basal dendritic Arc levels nor late increases in dendritic Arc at $60 \mathrm{~min}$ after DHPG (Fig. 1C). Fostriecin (100 nM), a $\mathrm{PP} 2 \mathrm{~A}$ inhibitor that is structurally different from $\mathrm{OA}$ and 10,000 times more selective for PP2A over PP1 (Swingle et al., 2007), also blocked mGluR-induced increases in early dendritic Arc (Fig. 1D). Interestingly, $100 \mathrm{~nm}$ fostriecin (Fig. $1 D_{2}$ ) or a higher concentration of OA (100 nM; basal, $100 \pm 8 \% ; 100$ 
A ACSF

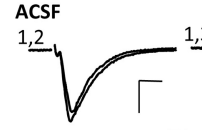

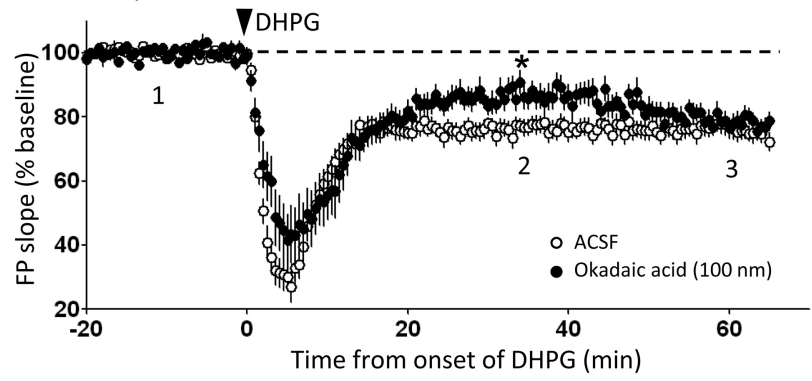

$\mathrm{C}_{1}$ Early

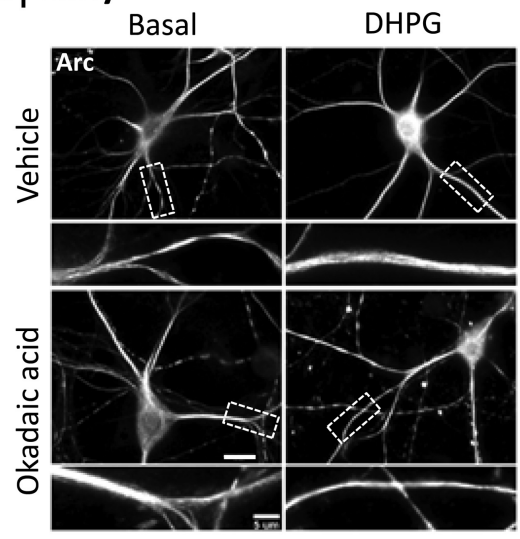

\section{$D_{1}$ Early}

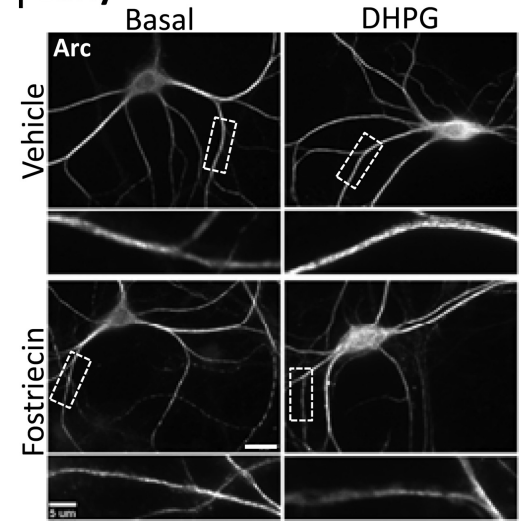

$\mathrm{C}_{2}$ Early (5 min)

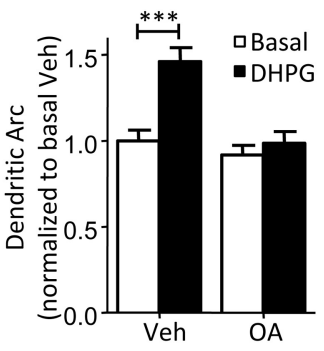

$\mathbf{D}_{2}$

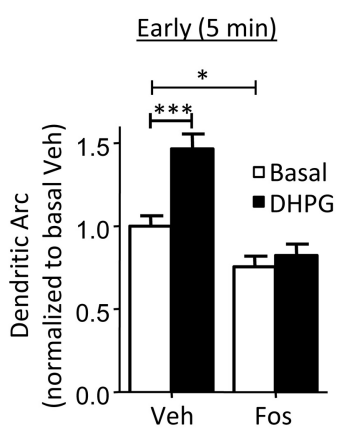

B

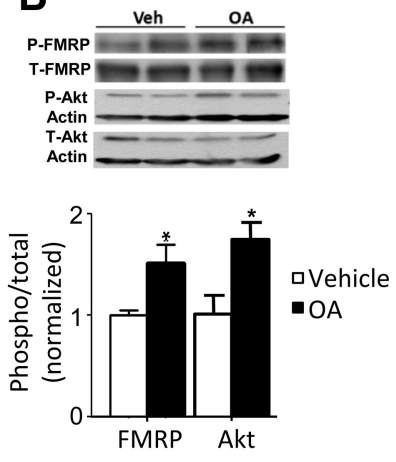

$C_{3}$ $\underline{\text { Late }(60 \mathrm{~min})}$

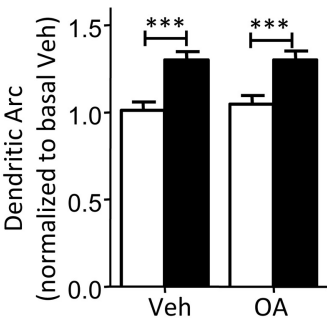

E

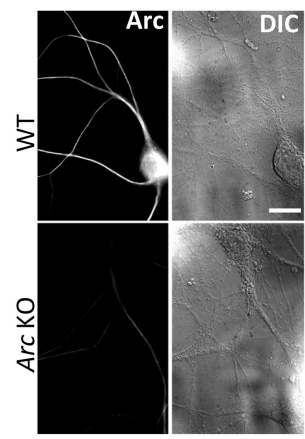

Figure 1. PP2A inhibitors reveal a rapid, early phase of $\mathrm{mGluR}$-induced LTD and synthesis of dendritic Arc. A, Incubation of acute rat hippocampal slices in the PP2A inhibitor, $0 \mathrm{~A}$ (100 nm; $1-3 \mathrm{~h}$ ), significantly reduces mGluR-LTD by DHPG (100 $\mu \mathrm{m} ; 5 \mathrm{~min})$ at $30-40 \mathrm{~min}$ (ACSF, $\left.76 \pm 2 \% ; 0 \mathrm{~A}, 86 \pm 3 \% ;{ }^{*} p<0.05\right)$ but not at $50-60 \mathrm{~min}(\mathrm{ACSF}, 76 \pm 3 \% ; 0 \mathrm{~A}, 80 \pm 2 \%)$. Plotted are average $( \pm$ SEM) initial slope values of FPs normalized to the pre-DHPG baseline. Inset, FP waveforms from a representative experiment are taken at the time points indicated on the graph $(1,2$, and 3$)$. Calibration: $0.2 \mathrm{mV}, 10 \mathrm{~ms}$. B, Pretreatment of acute rat hippocampal slices with $100 \mathrm{~nm} \mathrm{OA}(3 \mathrm{~h})$ increased the phosphorylated (S499) FMRP (P-FMRP) and phosphorylated Akt (P-Akt). Top panel, Representative Western blot of P-FMRP and total FMRP, and P-Akt and total Akt from vehicle $\left(\mathrm{H}_{2} \mathrm{O}\right)$ - and OA-treated slices. Bottom panel, Quantification of P-FMRP normalized to total FMRP (Veh, $1.00 \pm 0.05 ; 0 \mathrm{~A}, 1.51 \pm 0.19 ; n=3$ rats) and P-Akt normalized to total Akt (Veh, $1.00 \pm 0.19 ; 0 \mathrm{~A}, 1.73 \pm 0.17 ; n=2$ rats). Statistical analysis was by Student's $t$ test, $p<0.05$. C, Application of $0 \mathrm{~A}(10 \mathrm{~nm} ; 1 \mathrm{~h})$ prevents the rapid but not late increase in dendritic Arc in response to the Gp1 mGluR agonist DHPG (100 $\mu \mathrm{m} ; 5 \mathrm{~min})$ in dissociated rat hippocampal neurons (DIV $18-21)$. $\boldsymbol{C}_{1}$, Representative images of Arc immunofluorescence at $5 \mathrm{~min}$ after DHPG application. Scale bars: 20 and $5 \mu \mathrm{m}$. $\boldsymbol{C}_{2}, \boldsymbol{C}_{3}$, Group averages ( \pm SEM) of quantified dendritic Arc immunofluorescence intensity at $5 \mathrm{~min}\left(\boldsymbol{C}_{2}\right)$ and $60 \mathrm{~min}\left(\boldsymbol{C}_{3}\right)$ after treatment with vehicle $\left(\mathrm{H}_{2} \mathrm{O}\right)$ or DHPG for each condition. Arc levels are normalized to basal, vehicle-treated neurons of the same culture preparation. $\boldsymbol{C}_{2}$, Vehicle, $1.00 \pm 0.06 ;$ DHPG (normalized to basal vehicle), $1.46 \pm 0.08 ; 0 \mathrm{~A}, 0.92 \pm 0.06 ; 0 \mathrm{~A}$ plus DHPG, $0.99 \pm 0.07$. C ${ }_{3}$, Vehicle, $1.00 \pm 0.05 ; \mathrm{DHPG}, 1.30 \pm 0.05 ; 0 \mathrm{~A}, 1.05 \pm 0.05 ; 0 \mathrm{~A} \mathrm{plus} \mathrm{DHPG}$, $1.30 \pm 0.05$. D, Pretreatment of neuronal cultures with a structurally distinct PP2A inhibitor, fostriecin (100 nm; $1 \mathrm{~h}$ ), lowers basal Arc and prevents the rapid increase in dendritic Arc in response to DHPG. $\boldsymbol{D}_{1}$, Representative images of Arc staining in dissociated hippocampal neurons (DIV 18-21) at $5 \mathrm{~min}$ after DHPG application. Scale bars, 20 and $5 \mu \mathrm{m}$. $\boldsymbol{D}_{2}$, Quantification of dendritic Arc immunofluorescence at $5 \mathrm{~min}$ after treatment with vehicle $\left(\mathrm{H}_{2} \mathrm{O}\right)$ or DHPG for each condition. Arc levels are normalized to basal, vehicle-treated cells. Vehicle, $1.00 \pm 0.06$; DHPG, $1.47 \pm 0.09$; Fos, $0.75 \pm 0.07$; Fos plus $D H P G, 0.82 \pm 0.07$. For group data in $C$ and $\boldsymbol{D}, N=$ number of cells per condition. Ten to 15 cells/culture were obtained for each condition, and the experiment was repeated in three to four independent culture preparations. Statistical analysis was as follows: two-way ANOVA, Bonferroni's post hoc comparison, ${ }^{*} p<0.05$, ${ }^{* * *} p<0.001$. $E$, Representative Arc immunofluorescence (Synaptic Systems $\alpha$-Arc antibody) and DIC images from cultures prepared from WT and Arc KO littermates demonstrating the specificity of the antibody. Scale bar, $20 \mu \mathrm{m}$. 
A

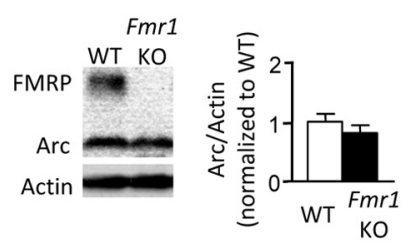

$\mathbf{B}_{1}$

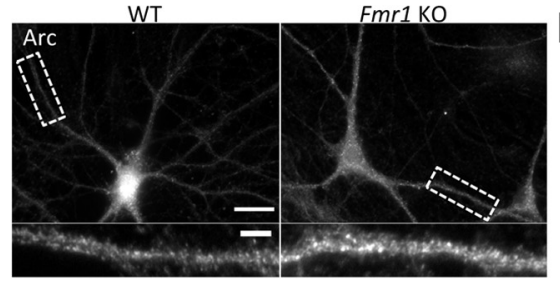

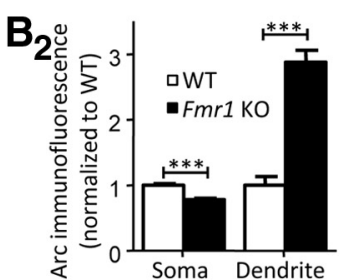

C
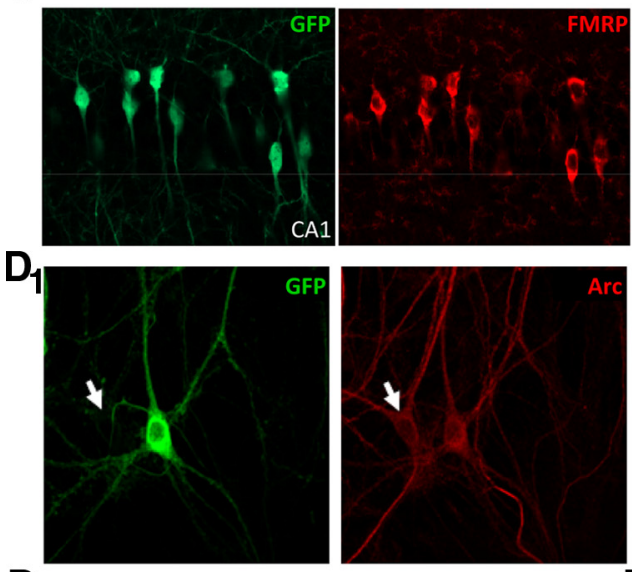

$\mathrm{D}_{2}$

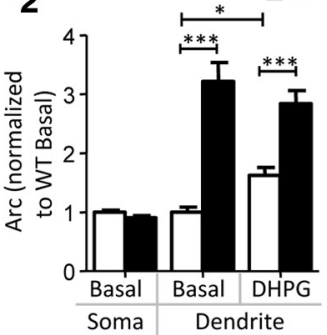

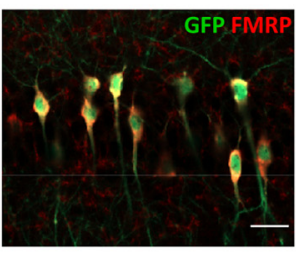

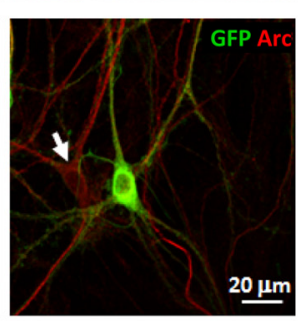

$20 \mu \mathrm{m}$

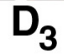

E
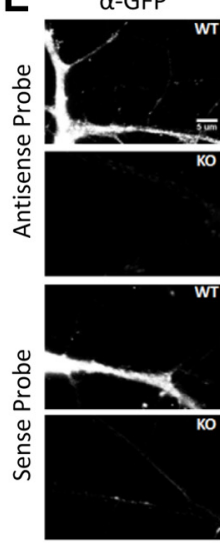

Vehicle

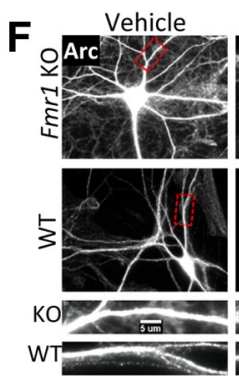

$\alpha$-dig
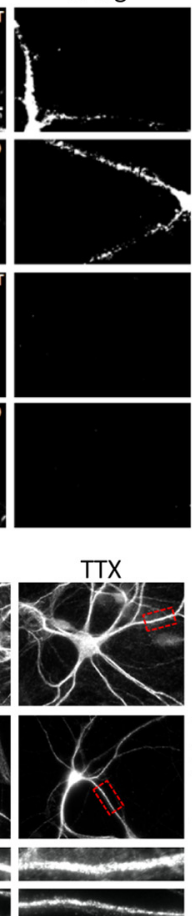

DIC
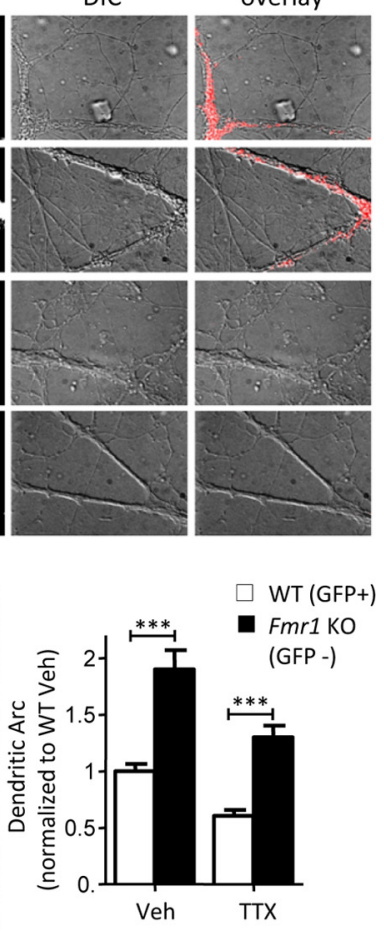

Figure 2. FMRP suppresses dendritic Arc protein levels. $\boldsymbol{A}$, Total Arc levels in Fmr1 $\mathrm{K} 0$ are unchanged as assessed by Western blotting of hippocampal homogenates from WT and Fmr $1 \mathrm{~K} 0$ mice. Left panel, Representative Western blot. Right panel, Group average of Arc/actin levels normalized to WT. $N=12$ mice per genotype. $\boldsymbol{B}$, Dendritic Arc immunofluorescence is greater in Fmr 1 KO neurons. $\boldsymbol{B}_{\boldsymbol{1}}$, Representative images of Arc immunofluorescence in dissociated hippocampal neurons (DIV 18-21) from WT and Fmr $1 \mathrm{KO}$. Scale bars, 20 and $5 \mu \mathrm{m}$. $\boldsymbol{B}_{\boldsymbol{2}}$, Group averages of quantified somatic and dendritic Arc immunofluorescence levels. Soma: WT, $1.00 \pm 0.02 ;$ Fmr1 K0, $0.78 \pm 0.02$. Dendrite: WT, 1.00 $\pm 0.13 ;$ Fmr 1 K0, 2.88 \pm 0.18 . C, Double immunofluorescence images of GFP (green) and FMRP (red) in hippocampal CA1 tissue sections of GFP/Fmr1 mosaic mice demonstrating the coexpression of GFP and FMRP. Scale bar, $20 \mu m$. D, Basal dendritic Arc levels are elevated in Fmr1 KO neurons of GFP/Fmr1 mosaic mice. D , Double immunofluorescence images of GFP (green) and Arc (red) in dissociated hippocampal neurons (DIV 18 - 21). The white arrows indicate Fmr1 KO (GFP-) cell. $\boldsymbol{D}_{\mathbf{2}}$, Left panel, Quantification of somatic and dendritic Arc immunofluorescence levels from neighboring WT and Fmr1 K0 neurons using a rabbit polyclonal Arc antibody from Synaptic Systems in GFP/Fmr 1 mosaic cultures. Values are normalized to WT (GFP+) basal [vehicle $\left(\mathrm{H}_{2} 0\right)$-treated] neurons of the same culture. Soma: WT, 1.00 $\pm 0.03 ; \mathrm{KO}, 0.91 \pm$ 0.04; dendrite: WT, $1.00 \pm 0.08 ; \mathrm{KO}, 3.21 \pm 0.32$. DHPG treatment of GFP/Fmr1 mosaic cultures increases dendritic Arc levels in WT neurons, but not in neighboring Fmr1 K0 neurons, where Arc levels are greatly elevated in basal conditions. WT (DHPG), $1.62 \pm 0.13 ; \mathrm{KO}$ (DHPG), $2.84 \pm 0.23$. Right panel, Quantification of the ratio of dendritic Arc/MAP2 immunofluorescence in neighboring WT and Fmr 1 KO neurons from GFP/Fmr1 mosaic cultures. $\boldsymbol{D}_{3}$, Quantification of somatic and dendritic Arc immunofluorescence levels from neighboring WT and Fmr 1 KO neurons cultured from GFP/Fmr1 mosaic mice using different Arc polyclonal antibody provided by Dr. Paul Worley (Lyford et al., 1995). Soma:WT, 1.00 $\pm 0.03 ; \mathrm{KO} 0,0.83 \pm 0.02$. Dendrite: WT, 1.00 $\pm 0.11 ; \mathrm{KO}$, 2.5 \pm 0.87. E, FISH reveals similar dendritic Arc mRNA levels in dissociated cultured WT and Fmr1 KO neurons prepared from hippocampi of GFP/Fmr1 mosaic mice. $\alpha$-GFP column, GFP staining identifies WT $(\mathrm{GFP}+)$ and Fmr1 KO (GFP-) cells. $\alpha$-dig column, Digoxigenin staining identifies hybridized digoxigenin-labeled antisense and sense (control) oligo-probes. Arc sense probes are unstained. DIC column, DIC images of dendrites. Overlay column, Overlay images of digoxigenin-labeled probes (red) on DIC images of respective dendrites. Scale bar, $5 \mu \mathrm{m}$. $\boldsymbol{F}$, Neuronal activity does not affect the difference in basal dendritic Arc levels between WT and Fmr 1 K0. Left panel, Representative images of Arc staining in WT and Fmr 1 KO neurons from GFP/Fmr 1 mosaic mice. Scale bar, $5 \mu$ m. Right panel, Quantification of basal dendritic Arc levels in vehicle $\left(\mathrm{H}_{2} 0\right)$ and TTX (1 $\left.\mu \mathrm{m} ; 14-18 \mathrm{~h}\right)$. Values are normalized to WT in vehicle. Veh: WT, 1.00 $\pm 0.06 ;$ Fmr1 K0, 1.90 $\pm 0.18 ;$ TTX: WT, $0.61 \pm$ $0.05 ; F m r 1 \mathrm{KO}, 1.30 \pm 0.10$. For group data in $\boldsymbol{B}, \boldsymbol{D}$, and $\boldsymbol{F}, N=$ number of cells per condition. Ten to 15 cells/culture were obtained for each condition, and experiment was repeated in three to four independent culture preparations. Statistical analysis was by two-way ANOVA, Bonferroni's post hoc comparison: ${ }^{*} p<0.05,{ }^{* *} p<0.01,{ }^{* * *} p<0.001$.

nM OA, $72 \pm 6 \%$ ) that causes hyperphosphorylation of FMRP (Narayanan et al., 2007) suppressed basal dendritic Arc levels. To confirm the specificity of the anti-Arc antibody, we performed immunocytochemistry in dissociated hippocampal neuron cultures prepared from wild-type and Arc KO littermates (Wang et al., 2006) (Fig. 1E).

\section{Dendritic Arc levels are elevated in Fmr1 KO neurons}

To determine how FMRP and its phosphorylation regulate Arc, we next used WT and Fmr1 KO mice. Arc mRNA interacts with
FMRP, either directly and/or indirectly, but it is unclear whether or how FMRP regulates protein levels of Arc (Zalfa et al., 2003; Park et al., 2008). Because Arc is an "LTD protein," we hypothesized that hippocampal Arc levels are elevated in Fmr1 KO neurons and contribute to the enhanced and protein synthesis-independent LTD. However, we did not observe any difference in total Arc levels in the hippocampi of WT and Fmr1 KO mice (Fig. 2A). FMRP has been suggested to function as a dendritic translational suppressor (Bassell and Warren, 2008). Therefore, we examined dendritic Arc levels using immunocytochemistry in dissociated 
neuron cultures prepared from WT and Fmr1 KO mouse hippocampi. Consistent with a translation suppression function of FMRP, Arc levels, as measured by immunofluorescence intensity, were enhanced in the dendrites of Fmrl KO neurons (Fig. 2B). In contrast, Arc levels were reduced in the soma of Fmrl KO neurons compared with WT neurons in sister cultures. To determine whether the enhanced dendritic Arc reflected a cell-autonomous effect of FMRP, we prepared dissociated hippocampal neurons from GFP/Fmr1 mosaic mice that were generated by crossing the Fmr1 KO line with mice that carry a GFP vector on the X chromosome (Hadjantonakis et al., 1998; Hanson and Madison, 2007). Due to $X$ inactivation, cells of heterozygous females are mosaic; that is, GFP + cells express FMRP ("wild type") and are intermingled with GFP- cells that are Fmr1 KO. Coexpression of FMRP and GFP in the hippocampus of GFP/Fmr1 mosaic mice was confirmed using immunohistochemistry (Fig. $2 \mathrm{C}$ ). In dissociated neuron cultures of GFP/Fmr1 mosaic mice, we observed similar results to that in the complete Fmrl KO. Fmr1 KO (GFP-) cells had elevated dendritic Arc levels compared with neighboring WT $(\mathrm{GFP}+)$ cells on the same coverslip (Fig. $\left.2 D_{1}, D_{2}\right)$, whereas the opposite trend was observed in the cell soma of KO (GFP-) neurons compared with WT (GFP+) neurons. Furthermore, Arc levels, when normalized to immunofluorescence for the dendritic marker MAP2, were elevated in Fmr1 KO dendrites (Fig. $2 \mathrm{D}_{2}$ ). This same compartment-specific regulation of Arc levels was confirmed with two different rabbit polyclonal antibodies to Arc (from Synaptic Systems; Fig. $2 B, D_{2}$; or from Dr. Paul Worley; Fig. 2D $D_{3}$ ) (Lyford et al., 1995).

Arc is an activity-dependent gene, and elevated Arc levels could be a result of enhanced activity or excitability of Fmrl KO neurons driving Arc transcription (Link et al., 1995; Lyford et al., 1995). We tested this idea in two ways, by examining the level of $\operatorname{Arc}$ mRNA in dendrites and the effects of activity blockade on dendritic Arc protein levels in WT and Fmr1 KO neurons. To measure dendritic Arc mRNA, we performed FISH for Arc mRNA in the GFP/Fmr1 mosaic cultures as described previously (Dictenberg et al., 2008). Previous work demonstrated that hippocampal Fmr1 KO neurons have normal steady-state and mGluR-induced trafficking of Arc mRNA (Steward et al., 1998a; Dictenberg et al., 2008). Consistent with these reports, we did not detect a difference in the levels of dendritic Arc mRNA between WT (GFP+) and neighboring Fmrl KO (GFP-) neurons in culture [Fig. 2E; WT: $1.00 \pm 0.08, n=53$; KO: $0.90 \pm 0.08$ (Arc FISH intensity; normalized to WT neurons), $n=52$ ]. To test the role of neuronal activity, GFP/Fmr1 mosaic cultures were treated for 14-18 h with TTX $(1 \mu \mathrm{M})$ to block action potentials. TTX reduced dendritic Arc levels in both WT and Fmrl KO neurons but did not abolish the difference between genotypes (Fig. $2 F$ ). In other words, dendritic Arc levels remain elevated in Fmr1 KO neurons in the presence of TTX. These results indicate that the elevated dendritic Arc in Fmrl KO dendrites is not a consequence of increased activity-dependent Arc transcription or dendritic mRNA levels and support a cell-autonomous role for FMRP in suppression of dendritic Arc translation.

\section{FMRP and PP2A are necessary for rapid, but not late,} mGluR-induced expression of dendritic Arc protein

To determine the role of FMRP phosphorylation in mGluRtriggered dendritic Arc increases, dissociated hippocampal cultures from WT and Fmrl KO mice were pretreated with OA (10 nM; Fig. 3). As observed in slices, OA treatment of WT cultures increased phosphorylated FMRP levels (Fig. 3C) (Narayanan et al., 2007). OA also blocked the rapid, mGluR-induced increases in dendritic Arc protein observed with immunocytochemistry (Fig. $3 A_{2}$ ) and total Arc protein observed with Western blotting (Fig. $3 B$ ). As observed in rat cultures, the late increases in dendritic Arc, observed at $1 \mathrm{~h}$ after DHPG, were resistant to OA (Fig. $3 A_{3}$ ). In contrast to WT cultures, DHPG treatment of Fmrl KO neuron cultures failed to evoke a rapid expression of dendritic Arc. However, DHPG evoked small, but significant increases in dendritic Arc in Fmr1 KO neurons at late time points (Fig. $3 D_{3}$ ) (Park et al., 2008). In the presence of OA, there was a trend for DHPG to increase dendritic Arc at late time points, but this did not reach statistical significance despite the large number of cells $\left(p=0.058\right.$; OA, $n=85$; OA+DHPG, $n=97$; Fig. $\left.3 D_{3}\right)$. Therefore, the role of PP2A in the late Arc increases in Fmrl KO neurons is unclear. To determine whether FMRP plays a cellautonomous role in mGluR-triggered and rapid increases in dendritic Arc levels, we treated GFP/Fmr1 mosaic cultures with DHPG and obtained similar results to those obtained in the complete Fmrl KO cultures - a rapid increase in dendritic Arc levels in WT (GFP+) neurons, but not in neighboring Fmrl KO (GFP-) dendrites (Fig. $2 D_{2}$ ). Interestingly, the level of dendritic Arc in DHPG-treated WT neurons did not reach that observed basally in Fmrl KO neurons (Fig. $2 \mathrm{D}_{2}$ ). These results provide support for two phases of mGluR-triggered Arc translation - an early, immediate phase that is mediated by PP2A and FMRP, and a late phase that is independent of these proteins and mediated either by other translational or transcriptional control mechanisms.

The translation inhibitor anisomycin blocks mGluR-LTD in hippocampal slices prepared from WT, but not Fmr1 KO mice (Hou et al., 2006; Nosyreva and Huber, 2006). Because of the evidence for Arc as an LTD protein (Park et al., 2008; Waung et al., 2008), we considered the possibility that mGluR-triggered, late increases in dendritic Arc in Fmrl KO neurons may be, like LTD, independent of de novo translation. Therefore, we tested the effects of anisomycin on the late increases in dendritic Arc in WT and Fmr1 KO neurons. In WT cultures, anisomycin completely blocked DHPG-induced dendritic Arc expression consistent with the anisomycin block of mGluR-LTD (Fig. $3 A_{4}$ ). Although DHPG evoked a small increase in dendritic Arc in anisomycintreated Fmrl KO neurons, this was not statistically significant (Fig. $3 D_{4}$ ). Therefore, this result indicates that the late increases in dendritic Arc in Fmrl KO neurons rely on translation (Fig. $3 D_{4}$ ), likely from mGluR-triggered increases in Arc mRNA (Park et al., 2008; Taylor et al., 2010). The fact that mGluR-LTD persists in Fmrl KO mice in the presence of anisomycin suggests that mGluR-LTD does not use the mGluR-induced, late Arc increases but instead relies on preexisting Arc protein (Park et al., 2008).

\section{Phosphomimic FMRP at S500 suppresses basal Arc, and dephosphorylation of FMRP is necessary for mGluR-induced, early dendritic Arc expression}

To determine whether the phosphorylation state of FMRP regulates basal and mGluR-triggered dendritic Arc expression, we performed rescue experiments with an N-terminally GFP-tagged wild-type FMRP (FMRP ${ }^{\mathrm{GFP}}$ ) and phosphorylation site mutants of FMRP. Our immunohistochemistry results in WT and Fmr1 KO mice suggested that FMRP suppresses basal dendritic Arc levels and is necessary for the mGluR-induced, rapid dendritic Arc synthesis. Consistent with this prediction, expressing FMRP ${ }^{\mathrm{GFP}}$ in dissociated Fmrl KO hippocampal neurons reduced basal dendritic Arc levels by $30 \%$ compared with sister Fmr1 KO cultures infected with GFP only (Fig. $4 A_{2}$ ). Furthermore, expression of FMRP ${ }^{\mathrm{GFP}}$ restored mGluRinduced, early dendritic Arc synthesis in these neurons (Fig. 4A). 

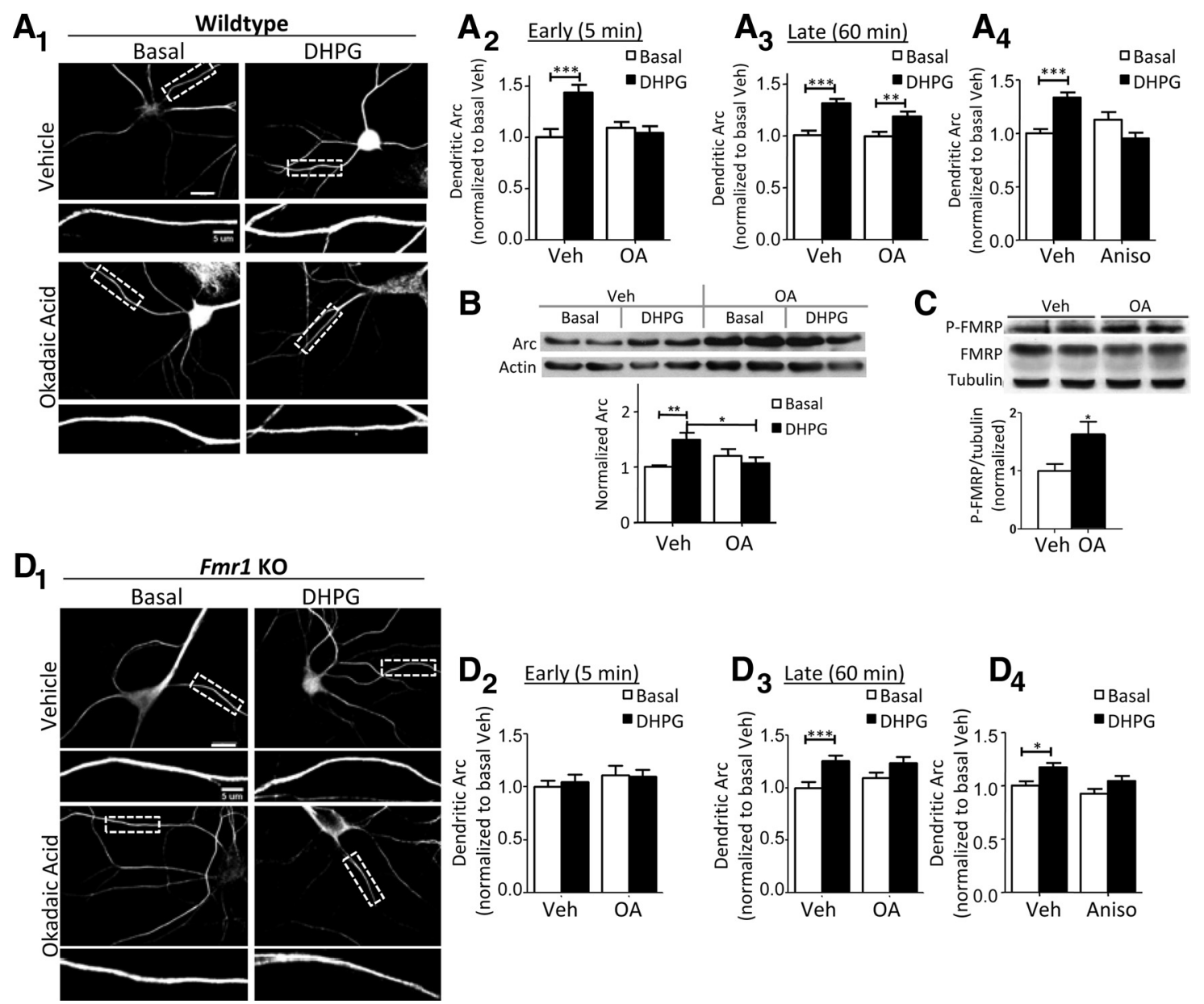

Figure 3. FMRP and PP2A are necessary for a rapid, mGluR-induced increase in dendritic Arc expression. $A$, Application of $0 \mathrm{~A}(10 \mathrm{~nm} ; 1 \mathrm{~h})$ blocks the rapid but not late increase in dendritic Arc protein in response to mGluR activation by DHPG (100 $\mu \mathrm{m} ; 5 \mathrm{~min})$ in dissociated WT mouse hippocampal neurons. $A_{1}$, Representative images of Arc immunofluorescence at 5 min after DHPG or vehicle $\left(\mathrm{H}_{2} \mathrm{O}\right)$ treatment. Scale bars, 20 and $5 \mu \mathrm{m}$. Quantification of dendritic Arc levels at $5 \mathrm{~min}\left(A_{2}\right)$ and $60 \mathrm{~min}\left(A_{3}\right)$ after addition of DHPG. Values are normalized to basal, vehicle-treated cells. $A_{2 \prime}$ Vehicle, $1.00 \pm 0.08 ; \mathrm{DHPG}, 1.43 \pm 0.08 ; 0 \mathrm{~A}, 1.09 \pm 0.06 ; 0 \mathrm{~A}$ plus DHPG, $1.04 \pm 0.07 . A_{3}$, Vehicle, $1.00 \pm 0.04 ; \mathrm{DHPG}, 1.31 \pm 0.04 ; 0 \mathrm{~A}, 0.99 \pm 0.05 ; 0 \mathrm{~A}$ plus DHPG, $1.19 \pm 0.05 . A_{4}$, The translation inhibitor, anisomycin (20 $\mu \mathrm{m} ; 20$ min before DHPG application), blocks mGluR-induced, late expression of dendritic Arc by DHPG. Values are normalized to basal, vehicle-treated cells. Vehicle, $1.00 \pm 0.04 ;$ DHPG, $1.34 \pm 0.05$; Aniso, $1.13 \pm 0.06$; Aniso plus DHPG, $0.95 \pm 0.05 . B$, Pretreatment of $0 \mathrm{~A}(10 \mathrm{~nm} ; 1 \mathrm{~h})$ prevents DHPG-induced, rapid, total Arc synthesis in dissociated WT mouse hippocampal neurons. Top panel, Representative Western blot of Arc and actin. Bottom panel, Quantification of Arc levels normalized to basal, vehicle-treated cells. Vehicle, $1.00 \pm 0.03$; DHPG, $1.49 \pm 0.13 ; 0 \mathrm{~A}, 1.20 \pm 0.12 ; 0 \mathrm{~A}$ plus DHPG, $1.07 \pm 0.11 ; n=6$ cultures. Actin was used as a loading control. C, P-FMRP level is elevated in $0 \mathrm{~A}$-treated (10 nm; $1 \mathrm{~h}$ ), dissociated WT mouse hippocampal neurons. Top panel, Western blot of whole-cell lysates from WT neurons in the presence of vehicle or OA. Bottom panel, Quantification of P-FMRP/tubulin normalized to vehicle-treated cells. Veh, $1.00 \pm 0.12 ; 0 \mathrm{~A}, 1.62 \pm 0.23$. Statistical analysis was by Student's t test, $p<0.05$. D, mGluR-induced, rapid synthesis of dendritic Arc by DHPG (100 $\mu \mathrm{m}, 5$ min) is absent in Fmr1 K0. $\boldsymbol{D}_{1}$ Representative images of Arc immunofluorescence at $5 \mathrm{~min}$ after DHPG in vehicle- or $0 \mathrm{~A}$-pretreated neurons. Scale bars, 20 and $5 \mu \mathrm{m}$. Quantification of dendritic $\operatorname{Arc~levels~at~} 5 \mathrm{~min}\left(\boldsymbol{D}_{2}\right)$ and 60 min $\left(\boldsymbol{D}_{\mathbf{3}}\right)$ after addition of DHPG. Values are normalized to basal, vehicle-treated cells. $\boldsymbol{D}_{2}$, Vehicle, $1.00 \pm 0.06$; DHPG, $1.05 \pm 0.07 ; 0 \mathrm{~A}, 1.11 \pm 0.09 ; 0 \mathrm{~A} \mathrm{plus}$ DHPG, $1.10 \pm 0.07$. $\mathbf{D}_{3}$, Effects of mGluR stimulation on dendritic Arc levels at $1 \mathrm{~h}$ after DHPG in vehicle- (basal, $1.00 \pm 0.06 ; \mathrm{DHPG}, 1.26 \pm 0.05$ ) or $0 \mathrm{~A}$-treated cultures $(0 \mathrm{~A}, 1.09 \pm 0.05 ; 0 \mathrm{~A}$ plus DHPG, $1.24 \pm 0.06 ; p=0.058) . \boldsymbol{D}_{4}, \mathrm{Effects}$ of mGluR stimulation on dendritic Arc levels at $1 \mathrm{~h}$ after DHPG in vehicle- (basal, $1.00 \pm 0.04 ; \mathrm{DHPG}, 1.17 \pm 0.04$ ) or anisomycin-treated cultures (Aniso, $0.92 \pm 0.04$; Aniso plus DHPG, 1.04 \pm 0.05 ). Values are normalized to basal, vehicle-treated cells. For all immunofluorescence quantification figures in $\boldsymbol{A}$ and $\boldsymbol{D}, N=$ number of cells per condition. Ten to 15 cells/culture were obtained for each condition, and experiment was repeated in three to four independent culture preparations. For all four group comparisons $(\boldsymbol{A}, \boldsymbol{B}, \boldsymbol{D})$, statistical analysis was by two-way ANOVA, Bonferroni's post hoc comparison: ${ }^{*} p<0.05 ;{ }^{* *} p<0.01 ;{ }^{* * *} p<0.001$.

The suppression of dendritic Arc levels by FMRP was not due to a general inhibition of dendrite size or protein expression because FMRP $^{\mathrm{GFP}}$ had no effect on dendritic immunofluorescence of $\beta 3$ tubulin (Fig. 4C). Lentiviral transfection of FMRP ${ }^{\mathrm{GFP}}$ into Fmr1 KO neurons did not affect total levels of Arc as assessed by Western blotting (Fig. $4 B_{2}$ ), similar to what we observe in WT cultures (Fig. $2 A)$. This is likely because FMRP ${ }^{\mathrm{GFP}}$ increased basal somatic Arc by $185 \pm 10 \%(n=191 ; p<0.001)$ compared with GFP-transfected neurons $(n=127)$. However, FMRP ${ }^{\mathrm{GFP}}$ transfection rescued DHPG-induced increases in total Arc levels in contrast to GFPinfected Fmrl KO cultures (Fig. $4 B_{3}$ ).

Since our findings implicate the FMRP phosphatase, PP2A, in mGluR-triggered dendritic Arc expression, we examined whether the dephosphorylation of FMRP at S500 regulated the mGluR-induced, early dendritic Arc synthesis. We used lentivirus to transfect dissociated hippocampal neurons of Fmrl KO mice with GFP-tagged phosphorylation site mutants of FMRP ${ }^{\mathrm{GFP}}$, namely a dephosphomimic (S500A) and a phosphomimic (S500D). The S500A-FMRP ${ }^{\mathrm{GFP}}$ and S500D-FMRP ${ }^{\mathrm{GFP}}$ are expressed at similar levels to FMRP ${ }^{\mathrm{GFP}}$ in hippocampal neurons and are properly localized to dendrites (Pfeiffer and Huber, 2007). Like wild-type FMRP, expression of S500D-FMRP ${ }^{\text {GFP }}$ in Fmr1 KO neurons suppressed basal dendritic Arc expression compared with GFP-infected sister cultures. However, S500D-FMRP did not rescue DHPG-induced stimulation of dendritic Arc levels (Fig. 5A). Expression of S500A-FMRP neither suppressed dendritic Arc protein nor rescued mGluR- 

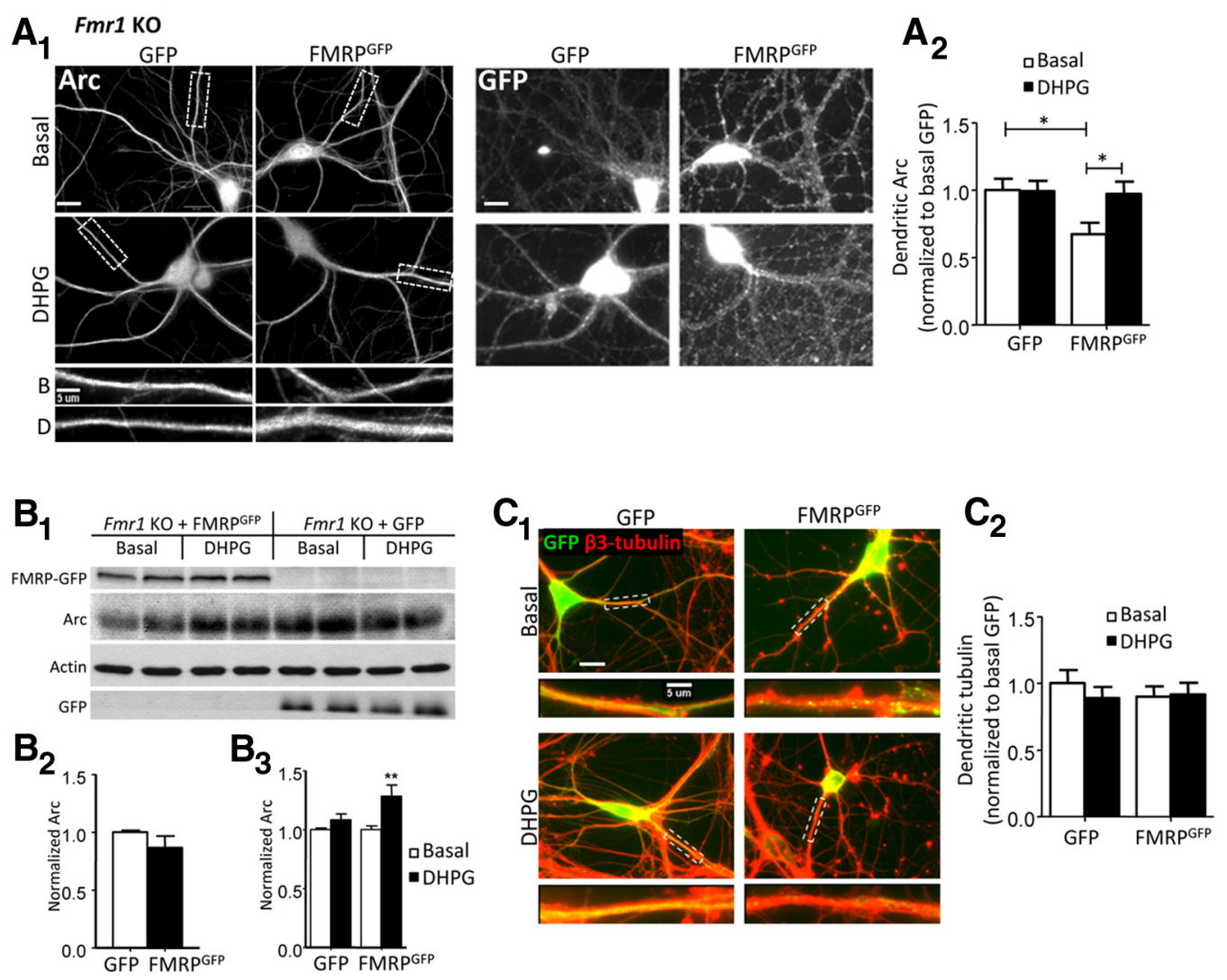

Figure 4. Acute expression of wild-type FMRP in $F m r 1 \mathrm{KO}$ neurons lowers basal dendritic Arc and rescues mGluR-induced, rapid expression of Arc. A-C, Fmr $1 \mathrm{KO}$ neuronal cultures were transfected using lentivirus expressing GFP (control) or an N-terminally GFP tagged FMRP (FMRP GFP). For quantification, values are normalized to GFP-infected, vehicle-treated (basal, $\left.\mathrm{H}_{2} 0\right)$ cells, except $\boldsymbol{B}_{3}$. $\boldsymbol{A}_{\boldsymbol{1}}$, Representative images of Arc and GFP immunofluorescence of Fmr $1 \mathrm{KO}$ neurons transfected with either GFP or FMRP GFP and then treated with vehicle or DHPG (100 $\mu \mathrm{m} ; 5 \mathrm{~min})$. Scale bars, 20 and $5 \mu \mathrm{m} . A_{2}$, Quantification of dendritic Arc levels. Basal (GFP), $1.00 \pm 0.08$; DHPG (GFP), $0.99 \pm 0.08$; basal (FMRP ${ }^{\text {GFP }}$ ), $0.67 \pm 0.08$; DHPG (FMRP GFP $), 0.97 \pm 0.09 . B_{1}$, Representative Western blot of Arc and actin from Fmr $1 \mathrm{KO}$ cultures transfected with either GFP or FMRP GFP. $\boldsymbol{B}_{2}$, GFP- and FMRP-transfected cells express similar levels of total Arc. GFP, $1.00 \pm 0.02 ;$ FMRP, $0.92 \pm 0.12$. $\boldsymbol{B}_{3 \text {, }}$ mGluR activation increases total Arc levels in FMRP GFP-transfected Fmr 1 KO cells, but not GFP-transfected. Values are normalized to respective basal conditions. Basal (GFP), 1.00 $\pm 0.02 ;$ DHPG (GFP), $1.11 \pm 0.06$; basal (FMRP GFP), $1.00 \pm 0.03$; DHPG (FMRP $\left.{ }^{\text {GFP }}\right), 1.29 \pm 0.13 ; n=5$ independent cultures. $C_{1}$, Representative images of double immunofluorescence for $\beta 3$-tubulin (red) and GFP (green) of infected cells treated with vehicle or DHPG. Scale bars, 20 and $5 \mu \mathrm{m}$. $C_{2}$, Tubulin levels are similar in GFP- and FMRP-infected cells. Basal (GFP), 1.00 \pm 0.10 ; DHPG (GFP), $0.89 \pm 0.08$; basal (FMRP GFP) $0.90 \pm 0.08$; DHPG (FMRP GFP) $0.92 \pm 0.09$. For immunofluorescence quantification $(A, C), N=$ number of cells per condition. Ten to 15 cells/culture were obtained for each condition, and experiment was repeated in three to four independent culture preparations. For all four group comparisons $\left(\boldsymbol{A}, \boldsymbol{B}_{3}, \boldsymbol{C}\right)$, statistical analysis by two-way ANOVA, Bonferroni's post hoC comparison: ${ }^{*} p<0.05 ;{ }^{* *} p<0.01$. For $\boldsymbol{B}_{2}$, Student's $t$ test was used.

stimulated dendritic Arc (Fig. 5B). These results support a model in which FMRP, when phosphorylated at S500, functions as a translational suppressor of Arc mRNA, and dephosphorylation at this site by PP2A is necessary for mGluR-triggered dendritic Arc expression.

\section{FMRP dephosphorylation at $\mathrm{S500}$ is required for mGluR-induced depression of mEPSCs}

FMRP and its phosphorylation state at $\mathrm{S} 500$ affect the basal and mGluR-induced rapid increases in dendritic Arc levels in cultured neurons. Thus, we examined the effects of FMRP and phosphorylation site mutants on mGluR-induced depression of synaptic transmission in dissociated hippocampal cultures. In dissociated hippocampal neuron cultures prepared from rat, DHPG-induced LTD is typically manifested as a decrease in the frequency of mEPSCs, which requires postsynaptic Tyr phosphatase activity and Arc, and correlates with decreases in postsynaptic AMPAR surface expression (Snyder et al., 2001; Xiao et al., 2001; Moult et al., 2006; Waung et al., 2008; Sanderson et al., 2011). These results support a postsynaptic expression mechanism for DHPG-LTD. In contrast to rat hippocampal cultures, DHPG (100 $\mu \mathrm{M} ; 5 \mathrm{~min}$ ) did not induce a depression of mEPSC frequency when applied to cultured WT mouse hippocampal neurons (105 $\pm 8 \%$ of baseline; $n=11$ cells) (Fig. 6 , Table 1$)$. However, in Fmrl KO cultures, DHPG induced a depression of mEPSC frequency ( $72 \pm 5 \%$ of baseline; $n=8$; measured at $5-15$ min after DHPG washout; Fig. 6). These results are consistent with the enhanced, DHPG-induced LTD of evoked synaptic transmission observed in Fmrl KO hippocampal slices (Huber et al., 2002). To test whether the enhanced mGluR-induced depression of mEPSC frequency in Fmrl KO neurons was due to an acute role of FMRP, as opposed to a developmental one, we expressed GFP (control) or FMRP GFP in Fmrl KO neurons using lentivirus. DHPG application to FMRP GFP -infected Fmr1 KO neurons did not evoke a depression of mEPSC frequency ( $114 \pm 6 \%$ of baseline; $n=11$; Fig. 6) and mimicked what was observed in WT neurons. In contrast, GFP-infected Fmr1 KO neurons displayed a reduction in mEPSC frequency after DHPG application (76 \pm $9 \%$ of baseline; $n=14$ ) and were not different from untransfected Fmr1 KO neurons. We next examined whether FMRP phosphorylation at $\mathrm{S} 500$ affected mGluR-induced depression of mEPSC frequency by expressing S500A-FMRP GFP or S500DFMRP GFP in Fmrl KO cells. Fmrl KO neurons expressing S500D-FMRP ${ }^{\text {GFP }}$, which suppresses dendritic Arc levels and mGluR-triggered Arc increases (Fig. 5), failed to display DHPG- 
induced depression of mEPSC frequency (125 $\pm 17 \%$ of baseline; $n=13$; Fig. 6 ). In contrast, cells expressing S500AFMRP ${ }^{\text {GFP }}$, which neither suppressed dendritic Arc nor rescued mGluR-induced Arc synthesis (Fig. 5), displayed a depression in mEPSC frequency with mGluR activation $(81 \pm 6 \%$ of baseline; $n=16)$. There were no significant differences in mEPSC amplitude, series resistance, holding current, or input resistance among the different genotypes or lentiviral expressed proteins (Table 1). These results support the hypothesis that FMRP, when phosphorylated at S500, suppresses basal dendritic Arc levels and inhibits mGluR-LTD (Fig. 7).

\section{Discussion}

An acute, cell-autonomous role for FMRP in Arc translation and LTD

mGluR-LTD is enhanced and independent of protein synthesis in Fmr1 KO mice (Huber et al., 2002; Hou et al., 2006; Nosyreva and Huber, 2006). However, whether FMRP plays an acute role in LTD or the nature of FMRP function in LTD is unknown. Here, we provide evidence that FMRP functions as a translational switch to regulate steady-state dendritic Arc levels and mGluR-triggered Arc synthesis during LTD. FMRP, when phosphorylated at S500, functions to repress steady-state dendritic Arc levels and LTD. In response to Gp1 mGluR stimulation, FMRP is rapidly dephosphorylated by PP2A (Narayanan et al., 2007), which is necessary for mGluR-triggered, rapid increases in dendritic Arc and LTD (Fig. 7). FMRP also serves a similar dual translational control for other target mRNAs, such as Sapap3 and Psd95 (Narayanan et al., 2007; Muddashetty et al., 2011; Coffee et al., 2012), suggesting that FMRP phosphorylation/dephosphorylation may be a common mechanism for FMRP-mediated translational control.

\section{PP2A and FMRP dephosphorylation are necessary for an immediate, early phase of mGluR-triggered Arc translation and LTD}

The role of protein Ser/Thr phosphatases in mGluR-LTD is unclear. OA was reported to enhance DHPG-LTD (Schnabel et al., 2001), although at a 10 times greater concentration than used here, which likely inhibited PP1 (Swingle et al., 2007). In contrast, another study observed normal mGluR-LTD in a transgenic mouse that expresses the SV40 small-t-antigen, a PP2A inhibitor (Nicholls et al., 2008). However, the level of PP2A activity in this transgenic mouse was not demonstrated. Differences in species and slice preparation among studies may also contribute to varying results. Here, we use a low OA concentration, which selectively inhibits PP2A (Gong et al., 2000) and find it attenuates an early, but not late phase of DHPG-LTD. Consistent with this finding, $\mathrm{OA}$ and a distinct PP2A inhibitor, fostriecin, block the immediate, $\mathrm{mGluR}$-induced increase in dendritic Arc levels, but not those at $1 \mathrm{~h}$ after DHPG. Like PP2A inhibition, mGluRinduced, immediate, but not late, dendritic Arc increases are absent in Fmr1 KO neurons. Expression of wild-type FMRP, but not S500A- or S500D-FMRP, rescues mGluR-induced, rapid Arc synthesis, thus implicating FMRP dephosphorylation. mGluR5 interacts directly with PP2A (Mao et al., 2005); and upon mGluR5 activation, PP2A dephosphorylates FMRP within 1-2 min (Narayanan et al., 2007). If phosphorylated FMRP functions to stall ribosomes as suggested (Ceman et al., 2003; Darnell et al., 2011), this would provide a mechanism to stimulate synthesis of specific proteins within minutes of mGluR5 stimulation. In support of this idea, we demonstrated that DHPG induced rapid ( $<5 \mathrm{~min}$ ) synthesis of Arc in dendrites (Waung et al., 2008). Importantly, Gp1 mGluRs also stimulate translation initiation and regulate elongation, which are required for mGluR-triggered translation of Arc and mGluR-LTD (Hou and Klann, 2004; Banko et al., 2006; Park et al., 2008). These general translational control mechanisms likely work in concert with FMRP dephosphorylation to achieve rapid and robust translational activation of specific mRNAs in response to mGluRs. 
A

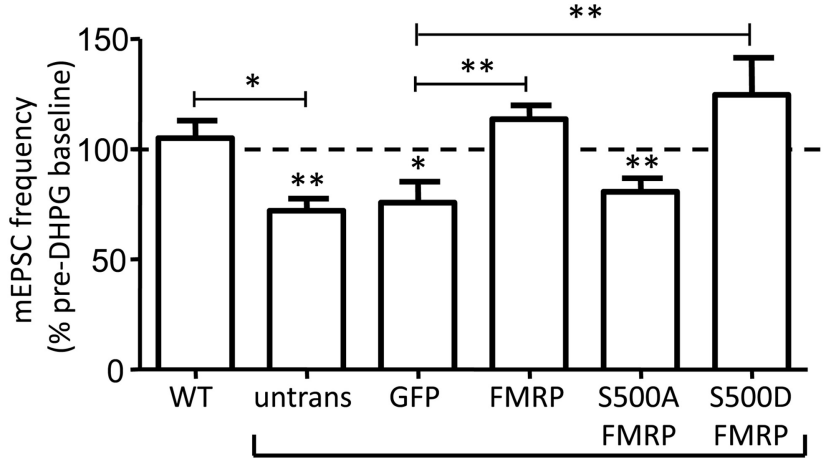

Fmr1 KO

B
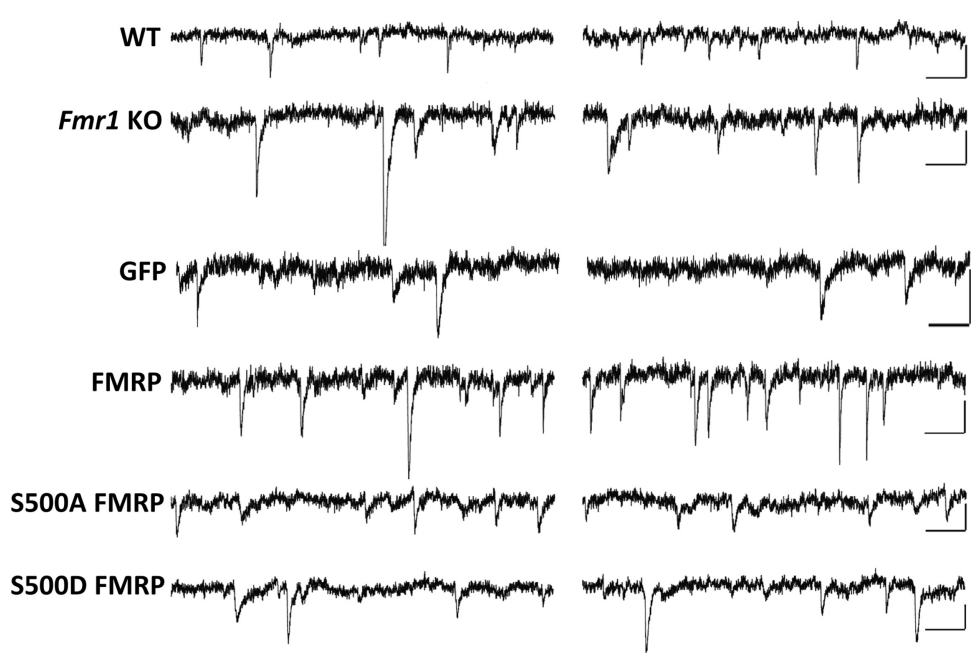

Figure 6. FMRP and its phosphorylation state at $\mathrm{S} 500$ affect mGluR-induced depression of mEPSCs in dissociated hippocampal neurons. $A$, Effects of brief mGluR activation DHPG ( $100 \mu \mathrm{m} ; 5 \mathrm{~min}$ ) on mEPSC frequency (measured at $5-15$ min after DHPG onset) in cultured untransfected WT or Fmr $1 \mathrm{KO}$ and $F m r 1 \mathrm{KO}$ neurons with lentiviral-mediated transfection of FMRP GFP S500A-FMRP GFP, or S500D-FMRP GFP. mEPSC frequency is normalized to a 5 min pre-DHPG baseline. WT untransfected, $105 \pm 8 \%$; Fmr 1 KO untransfected, $72 \pm 6 \%$; Fmr 1 K0 transfected with the following: GFP, $76 \pm 9 \%$; FMRP GFP $114 \pm 6 \%$; S500A-FMRP GFP $81 \pm$ $6 \%$; S500D-FMRP ${ }^{\text {GFP }}, 125 \pm 17 \%$. Statistical analysis was as follows: paired $t$ test, ${ }^{*} p<0.05,{ }^{* *} p<0.01$. For comparison among groups, one-way ANOVA, Newman-Keuls post hoc comparison was used: ${ }^{*} p<0.05,{ }^{* *} p<0.01$. B, Representative mEPSC recordings during baseline and $10 \mathrm{~min}$ after DHPG application from WT, Fmr1 K0, and Fmr1 K0 neurons transfected with GFP, FMRP $^{\text {GFP }}$ (FMRP), S500A-FMRP ${ }^{\text {GFP }}$ (S500A FMRP), or S500D-FMRP ${ }^{\text {GFP }}$ (S500D FMRP). Calibration: 10 pA, 100 ms.

Phosphorylated FMRP suppresses basal dendritic Arc levels and mGluR-LTD in cultured mouse neurons

Gp1 mGluR activation of cultured Fmr1 KO hippocampal neurons induces a robust depression of synaptic function as observed in acute hippocampal slices (Huber et al., 2002). We observed enhanced Arc levels in dendrites, but not the soma of Fmr1 KO neurons. The compartment-dependent changes in Arc protein of Fmr1 KO neurons may explain why changes in total Arc protein are not observed with Western blots. Elevated dendritic Arc levels are due to a cell-autonomous function of FMRP and not mediated by changes in dendritic Arc mRNA or neuronal activity. Basal dendritic Arc is decreased by lentiviral expression of FMRP ${ }^{\mathrm{GFP}}$ and S500D-FMRP ${ }^{\text {GFP }}$, but not S500A-FMRP ${ }^{\text {GFP }}$, indicating that FMRP phosphorylated at S500 suppresses dendritic Arc. This conclusion is supported by data that $\operatorname{Arc} \mathrm{mRNA}$ in dendrites is associated with the exon junctional complex, suggesting it has not undergone a pioneer round of translation (Giorgi et al., 2007). Our data implicate a cell-autonomous role for phosphorylated FMRP in mediating dendritic translational suppression of $\operatorname{Arc}$ mRNA.
The differential effects of FMRP on soma versus dendritic Arc levels were unexpected. In agreement with previous results (Steward et al., 1998a; Dictenberg et al., 2008), we did not observe a difference in dendritic Arc mRNA levels in Fmr1 KO neurons. FMRP may not regulate or interact with Arc mRNA in the cell soma either due to a change in its phosphorylation state or interactions with other proteins and RNA. Additional experiments are required to understand the mechanisms of Arc regulation in the soma.

Like basal Arc levels, acute lentiviral expression of FMRP $^{\text {GFP }}$ or S500DFMRP $^{\text {GFP }}$, but not S500A-FMRP GFP, suppresses LTD in Fmr1 KO neurons. This suggests that enhanced mGluR-LTD in Fmr1 KO neurons stems from elevated dendritic Arc levels, and phosphorylated FMRP in WT neurons functions to suppress Arc levels and LTD. To correlate the effects of mGluR activation on dendritic Arc levels and mGluR-LTD, we applied DHPG to WT and FMRP ${ }^{\text {GFP }}$-transfected Fmr1 KO neurons to induce mGluR-LTD (Huber et al., 2002; Nosyreva and Huber, 2006; Waung et al., 2008). Although mGluR activation increased dendritic Arc in these neurons, it did not depress mEPSCs. These results imply that mGluRinduced Arc levels are insufficient to support mGluR-LTD in cultured WT hippocampal neurons.

\section{FMRP may function as translational switch in mGluR-LTD}

Local translation of mRNAs is essential in neurons whose remote synapses must be individually regulated for normal development, plasticity, and cognition (Sutton et al., 2006). Cytoplasmic polyadenylation binding protein (CPEB) and Zip code binding protein (ZBP) are examples of other RNA binding proteins that differentially regulate translation or their mRNA targets in response to extracellular signals and changes in their phosphorylation state (Hüttelmaier et al., 2005; Richter, 2007). Importantly here, phosphorylation of CPEB-1 by Aurora-A kinase is required for mGluR- and translation-dependent LTD in Purkinje cells of the cerebellum and motor coordination (McEvoy et al., 2007). Our work implicates a similar repressor/activator function for FMRP phosphorylation in regulation of dendritic Arc levels and mGluR-LTD. Such dual regulation by RNA binding proteins may be a common mechanism for translation-dependent synaptic plasticity.

As with other FMRP target mRNAs (Hou et al., 2006; Muddashetty et al., 2007; Park et al., 2008), mGluR-triggered dendritic Arc synthesis is absent in Fmr1 KO neurons. This deficit may be because basal Arc levels are at a "ceiling" or FMRP may be required for mGluR-stimulated translation. S500D-FMRP GFP suppresses basal Arc but does not rescue mGluR-induced Arc synthesis, in contrast to wild-type FMRP. Therefore, our data implicate a requirement for FMRP dephosphorylation for 
Table 1. Electrophysiological properties of WT neurons and Fmr1 KO neurons with lentiviral-mediated expression of FMRP ${ }^{\text {GFP }}$ and FMRP phosphorylation site mutants

\begin{tabular}{|c|c|c|c|c|c|c|}
\hline & & Fmr1 KO & & & & \\
\hline & Untrans & Untrans & GFP & FMRP GFP $^{\text {GFP }}$ & S500A FMRP & S500D FMRP \\
\hline $\mathrm{SR}(\mathrm{M} \Omega)$ & & & & & & \\
\hline B & $24 \pm 2$ & $19 \pm 3$ & $24 \pm 2$ & $28 \pm 3$ & $19 \pm 1$ & $19 \pm 2$ \\
\hline D & $26 \pm 2$ & $20 \pm 3$ & $25 \pm 2$ & $26 \pm 3$ & $19 \pm 1$ & $18 \pm 1$ \\
\hline$R_{\mathrm{n}}(\mathrm{M} \Omega)$ & & & & & & \\
\hline B & $209 \pm 22$ & $221 \pm 26$ & $163 \pm 14$ & $206 \pm 24$ & $166 \pm 18$ & $141 \pm 21$ \\
\hline D & $224 \pm 22$ & $215 \pm 24$ & $171 \pm 15$ & $204 \pm 20$ & $179 \pm 24$ & $149 \pm 2$ \\
\hline$I_{H}(\mathrm{pA})$ & & & & & & \\
\hline$B$ & $-36 \pm 17$ & $-62 \pm 14$ & $-75 \pm 14$ & $-54 \pm 10$ & $-55 \pm 8$ & $-91 \pm 18$ \\
\hline D & $-81 \pm 17^{* *}$ & $-114 \pm 28^{* *}$ & $-91 \pm 13^{* *}$ & $-66 \pm 10^{*}$ & $-70 \pm 9^{* *}$ & $-105 \pm 15^{*}$ \\
\hline $\mathrm{mEPSC}$ frequen & & & & & & \\
\hline B & $1.4 \pm 0.3$ & $1.9 \pm 0.3$ & $1.3 \pm 0.2$ & $1.2 \pm 0.3$ & $1.6 \pm 0.2$ & $1.4 \pm 0.2$ \\
\hline D & $1.5 \pm 0.3$ & $1.4 \pm 0.3^{* *}$ & $1.0 \pm 0.2^{*}$ & $1.5 \pm 0.4$ & $1.3 \pm 0.2^{* *}$ & $1.6 \pm 0.3$ \\
\hline mEPSC amplitu & & & & & & \\
\hline B & $14 \pm 1$ & $19 \pm 2$ & $14 \pm 1$ & $15 \pm 1$ & $16 \pm 1$ & $16 \pm 1$ \\
\hline D & $13 \pm 1^{* *}$ & $18 \pm 2$ & $14 \pm 1$ & $15 \pm 1$ & $16 \pm 9$ & $15 \pm 1$ \\
\hline$V_{\mathrm{m}}(\mathrm{mV})^{a}$ & & & & & & \\
\hline B & $-53 \pm 1$ & $-54 \pm 1$ & $-50 \pm 2$ & $-53 \pm 1$ & $-53 \pm 1$ & $-52 \pm 1$ \\
\hline$N$ (no. of cells) & 11 & 8 & 14 & 11 & 16 & 13 \\
\hline
\end{tabular}

Untrans, Untransfected; SR, series resistance.

${ }^{a}$ Not corrected for junction potential.

The asterisks indicate that the DHPG-treated condition (D) is different from baseline (B). ${ }^{*} p<0.05 ;{ }^{* *} p<0.01$.

\section{A Wildtype}

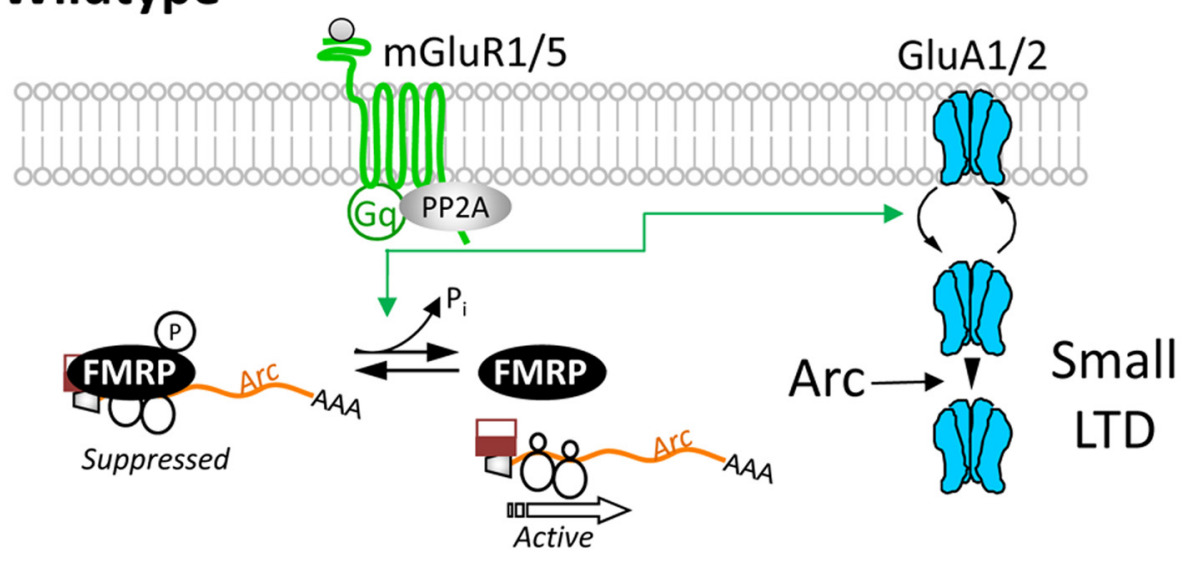

\section{B Fmr1 KO}

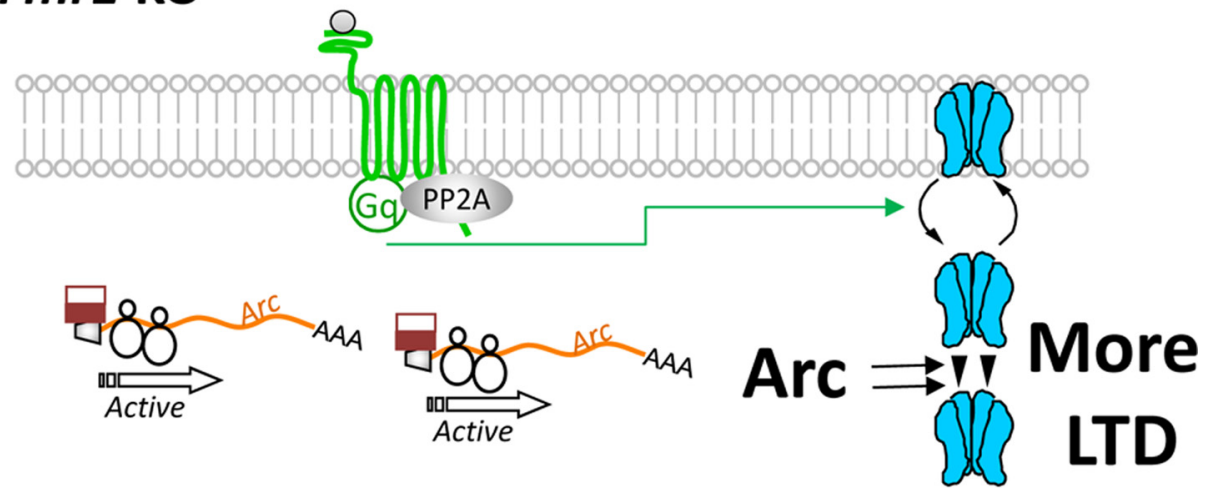

Figure 7. Working model of the acute role of FMRP regulation of Arc translation and mGluR-LTD. $\boldsymbol{A}$, In wild-type mice, phosphorylated FMRP functions to suppress Arc translation in dendrites under basal or unstimulated conditions. As yet unknown for Arc mRNA, the translational suppression by FMRP may occur at the initiation or elongation step. Gp1 mGluR agonism stimulates endocytosis of AMPA receptors (GluRA1 and 2) as well as PP2A-mediated dephosphorylation of FMRP (Narayanan et al., 2007). FMRP dephosphorylation contributes to activation of new synthesis of Arc (Figs. 1, 3,5), which is required to maintain the persistent endocytosis of AMPARs that underlie LTD (Fig. 1) (Park et al., 2008; Waung et al., 2008). B, In Fmr 1 KO mice, the loss of FMRP-mediated translational suppression of Arc leads to elevated steady-state levels of dendritic Arc (Fig. 2). Gp1 mGluR stimulation causes endocytosis of AMPARs; but because of the elevated basal dendritic Arc levels in Fmr1 KO dendrites (Fig. 2), no mGluR-stimulated synthesis of Arc is required to maintain LTD (Hou et al., 2006; Nosyreva and Huber, 2006). 
mGluR stimulation of dendritic Arc. The early phase of mGluRLTD in rat hippocampal slices relies, in part, on PP2A, the FMRP phosphatase (Narayanan et al., 2007), and Arc synthesis (Waung et al., 2008). Because mGluR-triggered Arc synthesis requires PP2A and FMRP dephosphorylation at S500, our data suggest that FMRP dephosphorylation regulates the early phase of mGluR-LTD in WT neurons. Interestingly, okadaic acid has a small effect on mGluR-LTD magnitude but completely blocks mGluR-triggered Arc synthesis in cultured neurons. This could be due to the protein synthesis-independent component of mGluR-LTD (Huber et al., 2000; Hou et al., 2006; Nosyreva and Huber, 2006) that may be mediated by existing Arc protein (Park et al., 2008; Waung et al., 2008) or posttranslational modifications (Moult et al., 2006). FMRP may also have functions in translational control that are independent of its phosphorylation state (Napoli et al., 2008).

How FMRP phosphorylation controls translation of its mRNA targets is evident from recent studies. FMRP phosphorylation at S499/500 suppresses PSD-95 translation by promoting a complex of the microRNA (miR-125a) and AGO2 with the 3'-UTR of Psd95 mRNA. Upon mGluR stimulation, FMRP is dephosphorylated and releases AGO2 from the mRNA (Muddashetty et al., 2011). For the majority of its mRNA targets, FMRP interacts with the coding sequence of the mRNA, where it stalls polyribosomes and inhibits translation elongation (Darnell et al., 2011). Interestingly, S500DFMRP associates more with stalled polysomes, while S500A-FMRP associates more with translating polysomes (Ceman et al., 2003), suggesting that FMRP phosphorylation may contribute to ribosome stalling.

\section{An FMRP-mediated translational switch may function as a form of metaplasticity in response to Arc-inducing experience} $A r c$, an immediate-early gene, is induced in hippocampal neurons in response to novelty and spatial exploration (Link et al., 1995; Lyford et al., 1995; Guzowski et al., 1999) and is required for hippocampal-dependent learning (Guzowski et al., 2000; Plath et al., 2006). Upon induction, Arc mRNA is rapidly transported to dendrites (Steward et al., 1998b), where evidence suggests it is translationally suppressed (Giorgi et al., 2007), likely by FMRP (this study). Subsequent synaptic activation of mGluRs and PP2A may stimulate dendritic Arc translation and cause synaptic plasticity, but only in recently activated neurons with suppressed dendritic Arc mRNA. An FMRP-mediated translational switch may function as a metaplasticity mechanism (Abraham and Bear, 1996) in which the activation history of the neuron, as determined by Arc induction, affects subsequent synaptic plasticity of its inputs. Such metaplasticity may contribute to the encoding of $A r c$-inducing experiences and be deficient in fragile $\mathrm{X}$ syndrome.

\section{References}

Abraham WC, Bear MF (1996) Metaplasticity: the plasticity of synaptic plasticity. Trends Neurosci 19:126-130.

Abrahams BS, Geschwind DH (2008) Advances in autism genetics: on the threshold of a new neurobiology. Nat Rev Genet 9:341-355.

Antar LN, Afroz R, Dictenberg JB, Carroll RC, Bassell GJ (2004) Metabotropic glutamate receptor activation regulates fragile $\mathrm{X}$ mental retardation protein and FMR1 mRNA localization differentially in dendrites and at synapses. J Neurosci 24:2648-2655.

Banko JL, Hou L, Poulin F, Sonenberg N, Klann E (2006) Regulation of eukaryotic initiation factor $4 \mathrm{E}$ by converging signaling pathways during metabotropic glutamate receptor-dependent long-term depression. J Neurosci 26:2167-2173.

Bassell GJ, Warren ST (2008) Fragile X syndrome: loss of local mRNA regulation alters synaptic development and function. Neuron 60:201-214.
Bramham CR, Alme MN, Bittins M, Kuipers SD, Nair RR, Pai B, Panja D, Schubert M, Soule J, Tiron A, Wibrand K (2010) The Arc of synaptic memory. Exp Brain Res 200:125-140.

Ceman S, O'Donnell WT, Reed M, Patton S, Pohl J, Warren ST (2003) Phosphorylation influences the translation state of FMRP-associated polyribosomes. Hum Mol Genet 12:3295-3305.

Chowdhury S, Shepherd JD, Okuno H, Lyford G, Petralia RS, Plath N, Kuhl D, Huganir RL, Worley PF (2006) Arc/Arg3.1 interacts with the endocytic machinery to regulate AMPA receptor trafficking. Neuron 52:445-459.

Coffee RL Jr, Williamson AJ, Adkins CM, Gray MC, Page TL, Broadie K (2012) In vivo neuronal function of the fragile $\mathrm{X}$ mental retardation protein is regulated by phosphorylation. Hum Mol Genet 21:900-915.

Darnell JC, Fraser CE, Mostovetsky O, Stefani G, Jones TA, Eddy SR, Darnell RB (2005) Kissing complex RNAs mediate interaction between the fragile $\mathrm{X}$ mental retardation protein $\mathrm{KH} 2$ domain and brain polyribosomes. Genes Dev 19:903-918.

Darnell JC, Van Driesche SJ, Zhang C, Hung KY, Mele A, Fraser CE, Stone EF, Chen C, Fak JJ, Chi SW, Licatalosi DD, Richter JD, Darnell RB (2011) FMRP stalls ribosomal translocation on mRNAs linked to synaptic function and autism. Cell 146:247-261.

Dictenberg JB, Swanger SA, Antar LN, Singer RH, Bassell GJ (2008) A direct role for FMRP in activity-dependent dendritic mRNA transport links filopodial-spine morphogenesis to fragile $\mathrm{X}$ syndrome. Dev Cell 14:926-939.

Gabel LA, Won S, Kawai H, McKinney M, Tartakoff AM, Fallon JR (2004) Visual experience regulates transient expression and dendritic localization of fragile X mental retardation protein. J Neurosci 24:10579-10583.

Giorgi C, Yeo GW, Stone ME, Katz DB, Burge C, Turrigiano G, Moore M] (2007) The EJC factor eIF4AIII modulates synaptic strength and neuronal protein expression. Cell 130:179-191.

Gong CX, Lidsky T, Wegiel J, Zuck L, Grundke-Iqbal I, Iqbal K (2000) Phosphorylation of microtubule-associated protein tau is regulated by protein phosphatase $2 \mathrm{~A}$ in mammalian brain. Implications for neurofibrillary degeneration in Alzheimer's disease. J Biol Chem 275:5535-5544.

Guzowski JF, McNaughton BL, Barnes CA, Worley PF (1999) Environmentspecific expression of the immediate-early gene Arc in hippocampal neuronal ensembles. Nat Neurosci 2:1120-1124.

Guzowski JF, Lyford GL, Stevenson GD, Houston FP, McGaugh JL, Worley PF, Barnes CA (2000) Inhibition of activity-dependent Arc protein expression in the rat hippocampus impairs the maintenance of long-term potentiation and the consolidation of long-term memory. J Neurosci 20:3993-4001.

Hadjantonakis AK, Gertsenstein M, Ikawa M, Okabe M, Nagy A (1998) Non-invasive sexing of preimplantation stage mammalian embryos. Nat Genet 19:220-222.

Hanson JE, Madison DV (2007) Presynaptic FMR1 genotype influences the degree of synaptic connectivity in a mosaic mouse model of fragile $\mathrm{X}$ syndrome. J Neurosci 27:4014-4018.

Hou L, Klann E (2004) Activation of the phosphoinositide 3-kinase-Aktmammalian target of rapamycin signaling pathway is required for metabotropic glutamate receptor-dependent long-term depression. J Neurosci 24:6352-6361.

Hou L, Antion MD, Hu D, Spencer CM, Paylor R, Klann E (2006) Dynamic translational and proteasomal regulation of fragile $\mathrm{X}$ mental retardation protein controls mGluR-dependent long-term depression. Neuron 51:441-454.

Huber KM, Kayser MS, Bear MF (2000) Role for rapid dendritic protein synthesis in hippocampal mGluR-dependent long-term depression. Science 288:1254-1257.

Huber KM, Gallagher SM, Warren ST, Bear MF (2002) Altered synaptic plasticity in a mouse model of fragile $\mathrm{X}$ mental retardation. Proc Natl Acad Sci U S A 99:7746-7750.

Hüttelmaier S, Zenklusen D, Lederer M, Dictenberg J, Lorenz M, Meng X, Bassell GJ, Condeelis J, Singer RH (2005) Spatial regulation of betaactin translation by Src-dependent phosphorylation of ZBP1. Nature 438:512-515.

Iacoangeli A, Rozhdestvensky TS, Dolzhanskaya N, Tournier B, Schütt J, Brosius J, Denman RB, Khandjian EW, Kindler S, Tiedge H (2008) On $\mathrm{BC} 1 \mathrm{RNA}$ and the fragile X mental retardation protein. Proc Natl Acad Sci U S A 105:734-739.

Link W, Konietzko U, Kauselmann G, Krug M, Schwanke B, Frey U, Kuhl D 
(1995) Somatodendritic expression of an immediate early gene is regulated by synaptic activity. Proc Natl Acad Sci U S A 92:5734-5738.

Lois C, Hong EJ, Pease S, Brown EJ, Baltimore D (2002) Germline transmission and tissue-specific expression of transgenes delivered by lentiviral vectors. Science 295:868-872.

Lyford GL, Yamagata K, Kaufmann WE, Barnes CA, Sanders LK, Copeland NG, Gilbert DJ, Jenkins NA, Lanahan AA, Worley PF (1995) Arc, a growth factor and activity-regulated gene, encodes a novel cytoskeletonassociated protein that is enriched in neuronal dendrites. Neuron 14:433-445.

Mao L, Yang L, Arora A, Choe ES, Zhang G, Liu Z, Fibuch EE, Wang JQ (2005) Role of protein phosphatase 2A in mGluR5-regulated MEK/ERK phosphorylation in neurons. J Biol Chem 280:12602-12610.

McEvoy M, Cao G, Montero Llopis P, Kundel M, Jones K, Hofler C, Shin C, Wells DG (2007) Cytoplasmic polyadenylation element binding protein 1-mediated mRNA translation in Purkinje neurons is required for cerebellar long-term depression and motor coordination. J Neurosci 27:6400-6411.

Moult PR, Gladding CM, Sanderson TM, Fitzjohn SM, Bashir ZI, Molnar E, Collingridge GL (2006) Tyrosine phosphatases regulate AMPA receptor trafficking during metabotropic glutamate receptor-mediated long-term depression. J Neurosci 26:2544-2554.

Muddashetty RS, Kelić S, Gross C, Xu M, Bassell GJ (2007) Dysregulated metabotropic glutamate receptor-dependent translation of AMPA receptor and postsynaptic density-95 mRNAs at synapses in a mouse model of fragile X syndrome. J Neurosci 27:5338-5348.

Muddashetty RS, Nalavadi VC, Gross C, Yao X, Xing L, Laur O, Warren ST, Bassell GJ (2011) Reversible inhibition of PSD-95 mRNA translation by miR-125a, FMRP phosphorylation, and mGluR signaling. Mol Cell 42:673-688.

Napoli I, Mercaldo V, Boyl PP, Eleuteri B, Zalfa F, De Rubeis S, Di Marino D, Mohr E, Massimi M, Falconi M, Witke W, Costa-Mattioli M, Sonenberg N, Achsel T, Bagni C (2008) The fragile X syndrome protein represses activity-dependent translation through CYFIP1, a new 4E-BP. Cell 134:1042-1054.

Narayanan U, Nalavadi V, Nakamoto M, Pallas DC, Ceman S, Bassell GJ, Warren ST (2007) FMRP phosphorylation reveals an immediate-early signaling pathway triggered by group I mGluR and mediated by PP2A. J Neurosci 27:14349-14357.

Narayanan U, Nalavadi V, Nakamoto M, Thomas G, Ceman S, Bassell GJ, Warren ST (2008) S6K1 phosphorylates and regulates FMRP with the neuronal protein synthesis-dependent mTOR signaling cascade. J Biol Chem 283:18478-18482.

Nicholls RE, Alarcon JM, Malleret G, Carroll RC, Grody M, Vronskaya S, Kandel ER (2008) Transgenic mice lacking NMDAR-dependent LTD exhibit deficits in behavioral flexibility. Neuron 58:104-117.

Nosyreva ED, Huber KM (2006) Metabotropic receptor-dependent longterm depression persists in the absence of protein synthesis in the mouse model of fragile X syndrome. J Neurophysiol 95:3291-3295.

Padmanabhan S, Mukhopadhyay A, Narasimhan SD, Tesz G, Czech MP, Tissenbaum HA (2009) A PP2A regulatory subunit regulates C. elegans insulin/IGF-1 signaling by modulating AKT-1 phosphorylation. Cell 136:939-951.

Park S, Park JM, Kim S, Kim JA, Shepherd JD, Smith-Hicks CL, Chowdhury S, Kaufmann W, Kuhl D, Ryazanov AG, Huganir RL, Linden DJ, Worley PF (2008) Elongation factor 2 and fragile X mental retardation protein control the dynamic translation of Arc/Arg3.1 essential for mGluR-LTD. Neuron 59:70-83.

Penagarikano O, Mulle JG, Warren ST (2007) The pathophysiology of fragile X syndrome. Annu Rev Genomics Hum Genet 8:109-129.
Pfeiffer BE, Huber KM (2007) Fragile X mental retardation protein induces synapse loss through acute postsynaptic translational regulation. J Neurosci 27:3120-3130.

Plath N, Ohana O, Dammermann B, Errington ML, Schmitz D, Gross C, Mao X, Engelsberg A, Mahlke C, Welzl H, Kobalz U, Stawrakakis A, Fernandez E, Waltereit R, Bick-Sander A, Therstappen E, Cooke SF, Blanquet V, Wurst W, Salmen B, et al. (2006) Arc/Arg3.1 is essential for the consolidation of synaptic plasticity and memories. Neuron 52:437-444.

Richter JD (2007) CPEB: a life in translation. Trends Biochem Sci 32:279-285.

Sanderson TM, Collingridge GL, Fitzjohn SM (2011) Differential trafficking of AMPA receptors following activation of NMDA receptors and mGluRs. Mol Brain 4:30.

Schnabel R, Kilpatrick IC, Collingridge GL (2001) Protein phosphatase inhibitors facilitate DHPG-induced LTD in the CA1 region of the hippocampus. Br J Pharmacol 132:1095-1101.

Snyder EM, Philpot BD, Huber KM, Dong X, Fallon JR, Bear MF (2001) Internalization of ionotropic glutamate receptors in response to mGluR activation. Nat Neurosci 4:1079-1085.

Steward O, Bakker CE, Willems PJ, Oostra BA (1998a) No evidence for disruption of normal patterns of mRNA localization in dendrites or dendritic transport of recently synthesized mRNA in FMR1 knockout mice, a model for human fragile X mental retardation syndrome. Neuroreport 9:477-481.

Steward O, Wallace CS, Lyford GL, Worley PF (1998b) Synaptic activation causes the mRNA for the IEG Arc to localize selectively near activated postsynaptic sites on dendrites. Neuron 21:741-751.

Sutton MA, Ito HT, Cressy P, Kempf C, Woo JC, Schuman EM (2006) Miniature neurotransmission stabilizes synaptic function via tonic suppression of local dendritic protein synthesis. Cell 125:785-799.

Swingle M, Ni L, Honkanen RE (2007) Small-molecule inhibitors of Ser/ Thr protein phosphatases: specificity, use and common forms of abuse. Methods Mol Biol 365:23-38.

Taylor AM, Dieterich DC, Ito HT, Kim SA, Schuman EM (2010) Microfluidic local perfusion chambers for the visualization and manipulation of synapses. Neuron 66:57-68.

Viviani B (2006) Preparation and coculture of neurons and glial cells. Curr Protoc Cell Biol Chapter 2:Unit 2.7.

Volk LJ, Pfeiffer BE, Gibson JR, Huber KM (2007) Multiple Gq-coupled receptors converge on a common protein synthesis-dependent long-term depression that is affected in fragile $\mathrm{X}$ syndrome mental retardation. J Neurosci 27:11624-11634.

Wang KH, Majewska A, Schummers J, Farley B, Hu C, Sur M, Tonegawa S (2006) In vivo two-photon imaging reveals a role of Arc in enhancing orientation specificity in visual cortex. Cell 126:389-402.

Waung MW, Huber KM (2009) Protein translation in synaptic plasticity: mGluR-LTD, fragile X. Curr Opin Neurobiol 19:319-326.

Waung MW, Pfeiffer BE, Nosyreva ED, Ronesi JA, Huber KM (2008) Rapid translation of Arc/Arg3.1 selectively mediates mGluR-dependent LTD through persistent increases in AMPAR endocytosis rate. Neuron 59:84-97.

Xiao MY, Zhou Q, Nicoll RA (2001) Metabotropic glutamate receptor activation causes a rapid redistribution of AMPA receptors. Neuropharmacology 41:664-671.

Zalfa F, Giorgi M, Primerano B, Moro A, Di Penta A, Reis S, Oostra B, Bagni C (2003) The fragile X syndrome protein FMRP associates with BC1 RNA and regulates the translation of specific mRNAs at synapses. Cell 112:317-327.

Zukin RS, Richter JD, Bagni C (2009) Signals, synapses, and synthesis: how new proteins control plasticity. Front Neural Circuits 3:14. 